\title{
Egyptian Beverages: A Journey through Ancient to Modern Times
}

\author{
Mona M. Raafat El-Sayed ${ }^{1}$
}

and Mahinor A. Fouad ${ }^{2}$

\begin{abstract}
There is a strong line of continuity linking the history of Egyptian beverages since early history till our present time. The ancient Egyptians thrived on drinking beer, wine and fresh milk beside their usual water intake. Nowadays in Egypt, locally manufactured beer and wine still exist but their consumption is limited due to religious beliefs. Beverages in ancient Egypt were normally served during celebrations, funerals or banquets which is still the case.

This article attempts to explore the journey of manufacturing and consuming Egyptian beverages through history with the aim of assessing the possible sustainability. It is concluded that the outcome of the manufacturing techniques of beer, wine and milk have considerably changed. The methodology used was based on observing ancient artifacts/tomb paintings in addition to reviewing compiled literature from previous studies.
\end{abstract}

\section{Keywords}

Ancient Egypt, Modern Egypt, Beverages, Wine, Beer, Milk, Būẓa

\section{Introduction}

Beverages are an integral part of all humans lives. There is a strong line of continuity linking the history of Egyptian beverages since early history till our present time. The ancient Egyptians thrived on drinking beer, wine and fresh milk beside their usual water intake. Nowadays in Egypt, locally manufactured beer and wine still exist but their consumption is limited due to religious beliefs. Beverages in ancient Egypt were normally served during celebrations, funerals or banquets which is still the case.

\footnotetext{
1 Assistant Professor, Tourism Guidance Department, Faculty of Tourism and Hotel Management, Helwan University, Egypt. Email address: monaraafat@hotmail.com

2 Assistant Professor, Hotel Management Department, Faculty of Tourism and Hotel Management, Helwan University, Egypt. Email address: mahinorf@yahoo.com
} 
Accounts made by travellers to Egypt throughout the ages provided valuable descriptions of ancient Egyptians' eating habits with special reference to their food and beverage. Diodorus Siculus ${ }^{3}$ is quoted saying: "And it was the custom for the kings to partake of delicate food, eating no other meat than veal and duck, and drinking only a prescribed amount of wine, which was not enough to make them unreasonably surfeited or drunken. And, speaking generally, their whole diet was ordered with such continence that it had the appearance of having been drawn up, not by a lawgiver, but by the most skilled of their physicians, with only their health in view."

\section{Serving Beverages in ancient Egypt}

Beverages were normally served during celebrations, funerals or banquets besides the regular household consumption. A big number of feasts ${ }^{4}$ were celebrated by the ancient Egyptians. One can imagine all these feasts accompanied by lavish banquets including all sorts of food and drinks as a typical Egyptian tradition. However, Beer was most probably regularly offered in the household accompanying breakfast, with a slice of bread or meat or a piece of pie, as well as in modest banquets. On the other hand, wine was mostly served during more luxurious festivities and celebrations. ${ }^{5}$

Wisdom Instructions, since the Old Kingdom, were given by fathers to their sons advising them on how to behave when attending banquets. Kagemni's father instructed him "When you sit with a glutton, eat when his greed has passed. When you drink with a drunkard, take when his heart is content". Thus setting the rules for being polite and considerate to other people. ${ }^{6}$

\footnotetext{
${ }^{3}$ LIBRARY OF HISTORY, Book 1, Chapter 70, p. 245-247

http://penelope.uchicago.edu/Thayer/E/Roman/Texts/Diodorus_Siculus/1D*.html

Accessed on 27/10/2018

${ }^{4}$ These included several types, e.g.: Formal (these were celebrated throughout the country, for example the Feast of Inundation, the beginning of the seasons and the New Year), Local (these were region- or city-specific, like those held in honour of a specific god), Personal (folk feasts connected to a certain event or a group of people), Religious (these were in honour of the principal deities), Agricultural (these included the feasts of the Nile, harvest, ploughing, and the Renenutet, goddess of the harvest), and Funerary (these included the feasts of the dead in which families visited the tombs and graveyards of the deceased to offer them food).

${ }^{5}$ Mehdawy, M. and Hussein A. (2010) The Pharaoh's Kitchen: Recipes from Ancient Egypt's Enduring Food Traditions, The American University in Cairo press, Cairo New York, p. 12, 14

${ }^{6}$ The Instruction addressed to Kagemni, Papyrus Prisse, pp. 1-2. Lichtheim, M. (1975) Ancient Egyptian Literature, Vol I: The Old and Middle Kingdoms, University of California Press, p. 59-60.
} 
On contrast, some ancient Egyptians often drank till intoxication. Alcoholic drinks i.e. beer, wine and Shedeh (A fermented pomegranate drink), were plentiful at banquets. Specific kings were even mentioned to have been drunk, for example Mycerinus was the first king to be accused of exceeding the limits in drinking. Also, from the Late Period, Amasis's name was referred to. ${ }^{7}$ As for private individuals, several tomb paintings showing banquet scenes from the New Kingdom where guests are depicted throwing up after what seems like a case of excessive drinking. Theban tombs such as TT 38 (Tomb of Djeserkaraseneb) display scenes of overindulgence, where both genders are shown vomiting or even passing out after an excess of alcohol. ${ }^{8}$ Even earlier scenes from Middle Kingdom tombs at Beni Hasan such as the Tomb of Khety; show some people being carried by servants after, probably getting drunk and passing out. ${ }^{9}$ People normally drank big amounts of alcoholic beverages during religious festivities e.g. at Busiris, Sais, Buto, Heliopolis, and especially at Bubastis as described by the Classical historian, Herodotus ${ }^{10}$. Drinking in excess, supposedly, broke the barriers between the human mortals and the mighty deities. ${ }^{11}$

However, it should be mentioned that intoxication was frowned upon by ancient Egyptian sages. For example, the scribe Ani, advised his son to avoid the state of getting drunk. He said:

"Take not upon thyself. Boast not that ye can drink to drink a jug of beer. Thou speakest, and an unintelligible utterance issueth from thy mouth. If thou fallest down and thy limbs break there is no one to hold out a hand to thee. Thy companions in drink stand up and say 'Away from that sot'. If there cometh one to seek thee in order to question thee, thou art found lying on the ground and thou art like a child.",12

The most commonly consumed beverages in ancient Egypt were: beer, wine and milk. ${ }^{13}$ It is hard to stipulate that the ancient Egyptians knew distilled alcoholic beverages like what we call now brandies or liquors; for the art of

\footnotetext{
${ }^{7}$ Ghalioungui,P., Darby, W. and Grivetti, L. (1977) Food: Gift of Osiris, Vol 2, Academic Press, London, p. 582

${ }^{8}$ Ikram, S. (2001) "Banquet" in Redford, D.B. (ed): The Oxford Encyclopaedia of Ancient Egypt, Vol 1, Oxford University Press, p. 164.

9 Ghalioungui,P., Darby, W. and Grivetti, L. (1977) Food: Gift of Osiris, Vol 2, Academic Press, London, p. 583-4

${ }^{10}$ Herodotus II, 60. "After proceeding in this way all along the river course, they reach Bubastis, where they celebrate the feast with abundant sacrifices. More grape-wine is consumed at this festival than in all the rest of the year besides."

${ }^{11}$ Manniche, L. (1999) Egyptian Luxuries: Fragrance, Aromatherapy, and Cosmetics in Pharaonic Times, The American University in Cairo Press, Cairo, p. 94.

${ }^{12}$ Erman, A. (1927) The Literature of the ancient Egyptians, translated by A. M. Blackmann, London. Also Hassan,S. (2000) Aladab al-misri al-kadim, Mawsooaa misr al-kadima, Part 17, Nahda Misr Publication, Cairo, p.222-223

${ }^{13}$ The authors excluded water as it was naturally the most commonly consumed beverage.
} 
distillation was unknown, and the production of alcohol with high concentration rather than produced by natural fermentation was highly improbable. $^{14}$

\section{Beer:
Ancient Egyptian name: $\bar{\Delta}$ hnk.t ${ }^{15}$}

Beer was largely known to be made out of barley, just like bread ${ }^{16}$ the other staple of the ancient Egyptian diet. ${ }^{17}$ According to Erman, it had long been cited as ancient Egypt's national drink as well as a metaphor for the good life. ${ }^{18}$ Both bread and beer-making were generally performed at the same location. Egyptian beer had a slightly thick texture, and was highly nutritious, this is the reason why it was almost included with every meal for all categories. ${ }^{19}$ As a matter of fact, beer had a primary role in ancient Egypt as a daily food stuff, being a vitamin- and protein-rich caloric staple. Togethe with bread - as mentioned before- it was distributed as staple rations, i.e. wages in kind, to workers and soldiers. ${ }^{20}$

\section{Mythology}

Hathor was the mistress of drunkenness and inventor of beer, par excellence: A Roman emperor in the temple of Isis at Philae sang to her: "Mistress of Both Lands, Mistress of Bread, who made beer with what her heart created, and her hands prepared, She is the Lady of Drunkenness, rich in Feasts, Lady of Music, fond of Dances" ${ }^{\prime 21}$

\footnotetext{
${ }^{14}$ Ghalioungui,P., Darby, W. and Grivetti, L.(1977) Food: Gift of Osiris, Vol 2, Academic Press, London, p. 613

${ }^{15} \mathrm{~Wb}$ III, 117.

Hieroglyphs: Rosmorduc, Serge. (2014). JSesh Documentation. [online] Available at: http://jseshdoc.qenherkhopeshef.org [Accessed 26 Dec. 2018].

${ }^{16}$ Bread is still considered till our present time the main staple of the Egyptian diet. It is actually the main ingredient in every meal. Egyptians eat food with bread, not bread with food.

${ }^{17}$ Herodot. ii,77, Diodor. i, 34 , Strabo, xvii, Pliny xxii.25

${ }^{18}$ Erman, A. (1894) Life in Ancient Egypt, Macmillan, New York, p.196.

${ }^{19}$ Ikram, S. (2001) "Diet", in Redford, D.B. (ed): The Oxford Encyclopaedia of Ancient Egypt, Vol 1, Oxford University Press, p. 392.

${ }^{20}$ Geller, J. (1992) "From Prehistory to history: Beer in Egypt", in: Friedman, R. and Adams, B. (eds.). The Followers of Horus: Studies dedicated to Michael Allen Hoffman, Egyptian Studies Association Publication No. 2, Oxbow Monograph 20, p. 20.

${ }^{21}$ Junker, H. and Winter, E. (1965) Das Geburthaus des Tempels der Isis in Phila. Wien: Herman Boehlaus, p. 271
} 
Another poem, "The Hymn of the Seven Hathors", exalted the happiness she brought: "Our hearts exult on seeing the Majesty, for thou art the Mistress of Wreathes, The Lady of Dance, and Drunkenness without end" 22

Egyptians consumed a lot of beer in honour of Hathor during the "Beautiful Feast of the Valley", whereas it also prevented Sekhmet/Hathor to destruct mankind as per the famous legend of the "Destruction of Mankind" which was recorded in the "Book of the Heavenly Cow", , from the New Kingdom. One scholar had suggested that this story might have been improvised to justify feast of $=\Delta \overline{\mathrm{B}} \mathrm{h}$ Hathor. ${ }^{24}$

Mnk.t

and tnmj.t : Mnq.t ${ }^{25}$ was particularly a beer goddess. The name of $M n k . t^{26}$ could have been a pun, as the jars where beer was stored were known as mnk.t jars the same as with tnmj.t 27 whose deification of a beverage jar.

\section{History}

According to Diodorus ${ }^{28}(\mathrm{IV}, 2)$, the invention of beer is attributed to Dionysus whom the Greeks identified with Osiris (Her.,II, 42) ${ }^{29}$ thus Greeks believed that the Egyptians are given the credit for creating beer. However, Sumero-Akkadians may also share the claim. Simply, beer could have been

\footnotetext{
22 Junker, H. (1906). "Poesie aus der Spaetzeit.", Zeitschrift fur altegyptische Sprache und Altertumskunde, 43,101-127

23 "The Book of the Heavenly Cow" or "The book of the Cow of Heaven" was inscribed in five Theban Royal tombs of the New Kingdom: Tutankhamun, Seti I, Ramesses II, Ramesses III and Ramesses VI. Lichtheim, M. (1976) Ancient Egyptian Literature, Vol II: The New Kingdom, University of California Press, p. 197-199.

${ }^{24}$ Armour, R. A. (2001) Gods and Myths of Ancient Egypt, second edition, The American University in Cairo Press, Cairo, p. 88 - 89.

${ }^{25}$ For more information about Mnq.t, refer to Leitz, C. Lexikon Der Agyptischen Gotter und Gotterbezeichungen, Band III, Leuven 2002, p. 317-318. (LGG III, 317-318)

${ }^{26} \mathrm{~Wb}$ II, 90.
}

Hieroglyphs: Rosmorduc, Serge. (2014). JSesh Documentation. [online] Available at: http://jseshdoc.qenherkhopeshef.org [Accessed 26 Dec. 2018].

${ }^{27} \mathrm{~Wb} \mathrm{~V}, 312$.

Hieroglyphs: Rosmorduc, Serge. (2014). JSesh Documentation. [online] Available at: http://jseshdoc.qenherkhopeshef.org [Accessed 26 Dec. 2018]. For more information about tnmj.t refer to Leitz, C. Lexikon Der Agyptischen Gotter und Gotterbezeichungen, Band VII, Leuven 2002, p. 474. (LGG VII, 474)

${ }^{28}$ Diodorus Siculus. Library of History, Translated by C.H. Oldfather, C. Sherman, C.B. Welles, R.M. Geer and F.R. Walton, 12 Vols, New York 1933-1967. G.P. Putnam's Sons.

${ }^{29}$ Herodotus. Translated by George Rawlinson, 4 Vols. New York 1885: D Appleton and Co.

Herodotus. Translated by A.D. Godley, 4 Vols. New York 1920-30: G.P. Putnam's Sons.

Herodotus. Translated by A. Barguet and D. Roussel (in French). Bibliotheques de la Pleiade. Paris1964: Editions Gallimard. 
invented accidentally by the left-overs of dough for bread-making left to ferment in household bakeries. ${ }^{30}$

Prehistoric jars examined by Petrie in the early Nineteenth Century, e.g. the jars from Abadiyeh, were found to contain residues of beer. ${ }^{31}$ A few centuries later, the drink was mentioned in texts as early as the Third Dynasty, e.g. the Offering list on the Stela of Seker-kha-bau from his tomb at Saqqara, referred to as $(h n k t n d m t)$ sweet beer. ${ }^{32}$ Offering formulae (htp di nisw) since the Fifth Dynasty onwards readily mentioned bread and beer. This typical example is from the Stela of Tjetji (BM 614): "An offering which the king gives and Osiris, lord of Busiris, Foremost of the Westerners, lord of Abydos in all his shrines. Invocation offering of one thousand loaves of bread and beer, one thousand flesh of cattle, one thousand of fowl, one thousand of alabaster vessels and linen garments, one thousand of all things beautiful and pure." Pyramid texts, although only appeared in the late Fifth Dynasty, contained archaic spells mentioning several varieties of beer, e.g. deshret, khnem.s and Nubian. ${ }^{34}$

\section{Beer the "National Beverage"}

Although beer was an extremely popular beverage, as it was the usual drink of the commoners and the staple of the Egyptian diet (together with bread), wine was the beverage of the rich, par excellence. Athenaeus ${ }^{35}$ indicated this difference in the tale of its invention: "The Egyptian [nobility] became fond of wine and bibulous; and so a way was found among them to help those who could not afford wine, namely, to drink that made from barley; they who took it were so elated that they sang, danced and acted in every way like persons filled with wine." (Deipnos., I, 61)

The previously cited quotation could help in understanding the reason for the scarcity of data about beer in ancient Egypt, as it was customary to mention

\footnotetext{
${ }^{30}$ Ghalioungui,P., Darby, W. and Grivetti, L. (1977) Food: Gift of Osiris, Vol 2, Academic Press, London, p. 530-1.

${ }^{31}$ Petrie, W.M.F. (1901) Diospolis Parva. The Cemeteries of Abadiyeh and Hu, 1898-9, Egypt Exploration Fund 20, London, p. 32.

${ }^{32}$ Murray, M. A. (1905) Saqqara Mastabas, Part 1, London, p. 34.

${ }^{33}$ Nunn, J. F. (1996) Ancient Egyptian Medicine, University of Oklahoma press, Avon, p.13.

${ }^{34}$ For more information about the mention of "Beer" in Pyramid Texts, refer to T.G. Allen. (2005) The Ancient Egyptian Pyramid Texts, Society of Biblical Literature, Atlanta.

35 Athenaeus, The Deipnosophists (i.e., The Learned Banqueters). http://digicoll.library.wisc.edu/cgi-bin/Literature/Literatureidx? type=turn\&entity $=$ Literature.AthV1.p0062\&id $=$ Literature. AthV1\&isize $=\mathrm{M} \& \mathrm{pview}=\mathrm{hid}$ e. Accessed on 20/11/2018
} 
the customs and food habits of the rich rather than the poor during that era. The Greek and Roman travellers equated beer with poverty. ${ }^{36}$ On the other hand, beer was considerably cheaper due to the abundance of grain, as well as the ease of its production in comparison to the extensive technology and care required for the production of wine and the vinification process. Beer was thus next in preference to water, the most popular beverage in ancient Egypt. Beer recurs in many ancient Egyptian tales passed through all generations but wine is only mentioned in selected texts. ${ }^{37}$ A famous tale in which beer had an important role is the "Tale of the Two Brothers: Inpw and Bata" ${ }^{38}$. It is said that Anubis knew that something wrong happened to his brother when he saw froth of fermentation appearing in his beer, so he knew that this meant a bad omen. We later learn that he found the body of his brother. ${ }^{39}$

"The book of Thoth", as described in one papyrus, was found by a prince named Neferkaptah. Directly, after he found it, he wrote down the magical words of the book, then washed the ink off with beer. He drank the beer and so he had the wise words of Thoth within him and knew them by heart. ${ }^{40}$

Wisdom texts also refer to drinking beer, when discussing the proper food habits. The wiseman Duauf son of Khety, from the Eighteenth dynasty, presents this advice to his son Pepy: "be content if you are satisfied with three loaves of bread, and two cups of beer. If your stomach still feels hunger, resist it." 41

\section{Ancient Beer-making Techniques}

A brewery dating back to $3500-3400 \mathrm{BC}$ was identified as the earliest known in the Predynastic site of Hierakonpolis (HK 24A) in 1989 by Jeremy Geller, after examining the charred residue of some contents of a vat. Barley and wheat were recognised as undergone all phases of biosynthetic fermentation. The brewery contained at least six coarse ceramic vats in two

\footnotetext{
${ }^{36}$ Ghalioungui,P., Darby, W. and Grivetti, L. (1977) Food: Gift of Osiris, Vol 2, Academic Press, London, p. 532

${ }^{37}$ Lefebvre, G. (1949) Romans et Contes Egyptians de l'Epoque pharaonique, Paris: AdrienMaisonneuve, p. 11

${ }^{38}$ Papyrus D’Orbiney (British Museum 10183). After Lichtheim, M. (2001) Ancient Egyptian Literature, Vol II: The New Kingdom, University of California Press 1976, p. 204.

Also see: Armour, R. A. Gods and Myths of Ancient Egypt, second edition, The American University in Cairo Press, Cairo, p. 142 - 148.

39 Simpson, W.K. (2003) The Literature of Ancient Egypt: An Anthology of Stories, Instructions, Stelae, Autobiographies and Poetry, Third Edition, Yale University Press, p.87. Also, Armour, R. A. Gods and Myths of Ancient Egypt, second edition, The American University in Cairo Press, Cairo 2001, p. 146

${ }^{40}$ Armour, R. A. (2001) Gods and Myths of Ancient Egypt, second edition, The American University in Cairo Press, Cairo, p. 130-131.

${ }^{41}$ Hassan, S. (2000) Al-adab al-misri al-kadim, Mawsooa'a misr al-kadima, Part 17, Nahda Misr Publication, Cairo, p. 215
} 
parallel rows, four of which are still in situ. The combined volume of the beverage produced would have mounted up to 390 litres, which is undoubtedly exceeding the household needs, thus supporting the assumption that this site was a brewery. ${ }^{42}$

It could also be speculated that beer was normally made in houses particularly in outdoor structures similar to silos, as evident in wooden models from the Middle Kingdom. ${ }^{43}$ For example: Tomb of Meketre (TT280) at Thebes, dating to the reign of Amenemhat I, Twelfth Dynasty, incorporates a wooden model of a combined bakery and brewery (Fig 1). ${ }^{44}$ Another model was recovered from the tomb of Wepwawetemhat at Asyut, also dating back to the Middle Kingdom. It is kept now in the Museum of Fine Arts, Boston, accession no $04.1782{ }^{45}$ (Fig 2). A scene depicting the act of baking and brewing is from the tomb of $\mathrm{Ti}^{46}$ from the Old Kingdom at Saqqara. (Fig 3) Similar scenes are also available from Middle Kingdom tombs e.g. tomb of Intefiqer (TT60) at Thebes (Fig 4). New Kingdom examples are also noted but less frequent, for example from the tomb of Ken Amun at Thebes. ${ }^{47}$ Several statues depict brewing beer are available since the Old Kingdom, for

${ }^{42}$ Geller, J. (1992) "From Prehistory to history: Beer in Egypt", in: Friedman, R. and Adams, B. (eds.). The Followers of Horus: Studies dedicated to Michael Allen Hoffman, Egyptian Studies Association Publication No. 2, Oxbow Monograph 20, p. 21. For further information refer to the website: http://www.hierakonpolis-online.org/index.php/explore-the-predynasticsettlement/hk24-breweries-by-the-cultivation

${ }^{43}$ Mehdawy, M. and Hussein A. (2010) The Pharaoh's Kitchen: Recipes from Ancient Egypt's Enduring Food Traditions, The American University in Cairo press, Cairo New York, p. 3.

${ }^{44}$ Metropolitan Museum of Art, accession no: 20.3.12. Rogers Fund and Edward S. Harkness Gift, 1920. Twenty-four well-preserved wooden models were recovered during the excavations of the Metropolitan Museum in 1920 by Herbert Winlock from the serdab of the tomb of Meketre,reign of Amenemhat, 12th dynasty. Half of the collection is kept in the Egyptian Museum, Cairo while the rest are kept in the Metropolitan Museum of Art, New York. Retrieved from the website of the Metropolitan Museum of Art https://www.metmuseum.org/toah/works-of-art/20.3.12/ Accessed on 10/11/2018

${ }^{45}$ From Asyut, tomb 14 (Wepwawetemhat); from the excavations carried out by M. Chassinat for the Louvre. 1904: purchased from Kyticas in Cairo by Albert M. Lythgoe for the MFA as part of a group for $£ 617 / 16 / 6$. Purchased with funds from the Emily Esther Sears Fund. (Accession Date: January 1, 1904). Retrieved from https://www.mfa.org/collections/object/model-of-a-brewery-45322 Accessed on 10/11/2018.

${ }_{46}$ Daumas, F. and Goyon, G. (1939) Le Tombeau de Ti. Memoire de l'Institut Francais d'Archeologie Orientale (MIFAO), no 65. Cairo, Institut Francais d'Archeologie Orientale, plate LXVII .Scene on the wall facing the entrance of the storeroom, showing bread and beer-making.

${ }^{47}$ Norman de G. (1930) The tomb of Ken-Amun at Thebes, Vol. 1, Egyptian Expedition Publication no. 5. New York: Metropolitan Museum of Art. 
example the statue ${ }^{48}$ of Meret from the tomb of Nikauinpu, probably from Giza, Old Kingdom (Fifth or Sixth Dynasty). (Fig 5)

The basis of all beer production is the fermentation/brewing of starch in amylaceous cereals. Grain always contains a small quantity of directly fermentable sugar, but this is inadequate in amount to produce an alcoholic drink. ${ }^{49}$ As starch, itself, cannot ferment unless first split into fermentable sugar, so it is usually first subjected to malting; i.e. letting grain germinate, a process during which starch is converted into maltose, and considerable amounts of diastase are developed. In modern processes, sprouted grains of malt are then heated and dried to stop germination, then boiled with water, strained and incubated with yeast. In antiquity, however, malt was immediately worked into a dough and processed..$^{50}$

Whether yeast was known in ancient Egypt or not, is a matter of debate. Gruss $^{51}$ found material from beer jars and residue of mashing from various periods, to consist of grains of Emmer starch, yeasts, moulds and bacteria. The yeast consisted of a previously unknown species, and was accordingly named Saccharomyces winlocki, after Winlock who provided the material. Moreover, specimens from the Eighteenth Dynasty show uniform and pure form which suggests that yeast could have been prepared since that time. During Ptolemaic Era, yeast was well-known, and the profession of yeast maker, the Zymourghos, is sufficiently recognised. ${ }^{52}$

Nearly all Greek classical writers agreed on the fact that beer was made of barley during the Ancient Egyptian Era (Her., II, 77; Deipnos., I, 34; Diod., I, 3; Strabo, 17, 2, 5). The only exception was Pliny who stipulated that it was made out of corn (wheat). [N.H. ${ }^{53}$, XIX, XXIX].

Helck, after studying the daily supplies to the Court as listed in several papyri, and assuming that these constituted the basic materials of brewing, found out that malt ( $b \check{s} c$ ), dates, and wheat were utilized in the proportion

\footnotetext{
${ }^{48}$ Statue made out of coloured limestone. Kept at the Oriental Institute of the University of Chicago, No OIC_E_10635. For more details: http://giza.fas.harvard.edu/objects/6 $\overline{63} 3 \overline{4} /$ intro/

${ }^{49}$ Samuel, D. "Beer" in Redford,D. (editor) (2001): The Oxford Encyclopedia of Ancient Egypt, Vol 1, Oxford University Press, p. 171

${ }^{50}$ Ghalioungui,P., Darby, W. and Grivetti, L. (1977) Food: Gift of Osiris, Vol 2, Academic Press, London, p. 534

51 Gruess, J.. (1932) Untersuchung von Broten aus der Ägyptischen Sammlung der Staatlichen Museen zu Berlin, Zeitschrift fur Ägyptische Sprache und Altertumskunde (Z̈̈S), 68, 79-80.

${ }^{52}$ Ghalioungui,P., Darby, W. and Grivetti, L. (1977) Food: Gift of Osiris, Vol 2, Academic Press, London, p. 535-6

${ }_{53}$ Pliny, Natural History.
} 
2:2:1 in certain papyrus, on the contrary, proportions were different in other texts, one giving a ratio of dates to ( $b \check{s}$ ) equal to $2: 1 .^{54}$

Harris, after examining three specimens from Deir El Medina, concluded that the brewing residues are of barley. ${ }^{55}$ Also, a pottery vase from Deir E1 Medina, filled with barley remnants of beer straining is kept at the Agriculture Museum at Dokki, Cairo ${ }^{56}$. Hops were unknown for the ancient Egyptians, so they reverted to the use of other plants to give it the right flavour, therefore the lupin, skirret, and the root of an Assyrian plant were used. $^{57}$

The actual process, as carried out in the third to fourth centuries A.D. was described in a text attributed to Zosimos of Panapolis in Upper Egypt. Though it dates back to the Late Period, there is a possibility that it describes earlier techniques ${ }^{58}$. One method is described as follows: barley is soaked in water for a day, then it was spread and well aerated. Then it was remoistened, ground, worked into a dough and yeast was added. It was then left till the fermentation process was judged to be completed sufficiently, later the whole mass was strained through a cloth or a sieve. The beverage was hence filtered. Another method utilised dried bread, soaked in water, left to ferment in a warm place. ${ }^{59}$

The beer making process represented in the tomb of Ti at Saqqara, as interpreted by Wild (1966), is explained as follows: "In the lowest register, to the left, grain is being withdrawn from the stores, measured (second man in lower half, as indicated by a legend) and registered (first man in upper half). Two men at the other end of the panel hold pole-like pestles with which they alternately pound grain (zh) in a mortar. The remaining workmen are composed of groups, each made of a kneeling woman grinding grain on a hollow stone and realistically spilling it onto the floor, facing a squatting

\footnotetext{
${ }^{54}$ Helck, W. (1971). Das Bier im Alten Ägypten. Berlin: Gesellschaft fur die Geschichte und Bibliographie des Brauwesens. E.V. Institut fur Garungsgewerbe und Biotechnologie.

${ }^{55}$ Lucas, A. (1962). Ancient Egyptian Materials and Industries. 4th edition. Edited by J.R. Harris. London: Edward Arnold.

${ }^{56}$ Ghalioungui,P., Darby, W. and Grivetti, L. (1977) Food: Gift of Osiris, Vol 2, Academic Press, London, p. 537

${ }^{57}$ Romant, B. (1986) (translated by J. Smith). Life in Egypt in Ancient Times, Editions Minerva, S.A. Geneve, p. 64

${ }^{58}$ Wild, H.(1966) "Brasserie et Panification au tombeau de Ti”, BIFAO,64, pp. 95-120

${ }^{59}$ For more information see Montet, (1958), p. 253; Lucas, (1962) p. 14. Ghalioungui,P., Darby, W. and Grivetti, L. (1977) Food: Gift of Osiris, Vol 2, Academic Press, London, p. 538
} 
companion holding a rounded object that, from the legend, may be identified as a cribble (nk (r) b̌s $)$. The grain in all these scenes is $b \check{s}$ ?

"In the middle register, to the right, grain (called zwt) is moistened by a standing workman plunging his arm in a reclining ovoid jar. Below him, to his right, a kneeling man is kneading into dough a mass of $t$-w3d) green bread, possibly malt from the jar above. The third man is working a batter into an oblong loaf called in the legend (pzn). The fourth carries to the brewer and to the baker pzn, and loaves of other shapes on a tray. From left to right, moulds are being heated; a worker is pouring a liquid or semi-liquid preparation (? malt) into a jar; and the third is macerating bread, probably with water, into a basket that filters into an earthenware jar. Finally, the uppermost register illustrates addition of a substance called (sgnn) (Possibly an aromat), supervision by a scribe, brewing, filtering and filling and sealing the jars."

Comparing the previously described method with New Kingdom representations e.g. tomb of Ken-Amon, shows minimal difference, especially in the shape of the loaves and jars, the loaves being broader and fatter after baking moulds had been replaced by ovens; and the jars being of many different shapes. ${ }^{60}$

Filtering beer is noted in the Ebers papyrus in prescription (Eb., LIII, 311) which recommends straining a mixture "as is done for beer"; confirming some of the above interpretation are many models of strainers found in ancient tombs. An Old Kingdom limestone model of a perforated basket superimposed on a receiving jar is on view at the Dokki Agricultural Museum, Cairo; and two strainers, made of gesso-covered wood, with a central disk of perforated copper, were found in the tomb of Tutankhamen. ${ }^{61}$

\section{Modern Beer-Making Techniques}

"Birra Stella kabira" is probably the most recalled by earlier modern Egyptian generations. It was a European-style lager in big brown bottles. Apparently, this was not the oldest in town but an older, more crude, version is the Egyptian " $B \bar{u} z a$ ". This beverage was definitely not for the elite. It was mostly consumed by those who could not afford bottled beer. Büza was described by Morcos ${ }^{62}$ as "a thick pale yellow beverage with a yeasty or alcoholic odour and agreeable taste" or as "thin gruel...contain[ing] much yeast,...in a state of active fermentation and made from coarsely ground

${ }^{60}$ Ghalioungui,P., Darby, W. and Grivetti, L. (1977) Food: Gift of Osiris, Vol 2, Academic Press, London, p. 538-9

${ }^{61}$ Ghalioungui,P., Darby, W. and Grivetti, L. (1977) Food: Gift of Osiris, Vol 2, Academic Press, London, p. 538-9

${ }^{62}$ Morcos, S. R., S. M. Hegazi and S. T. El-Damhougy.(1973) "Fermented Foods in Common Use in Egypt II. The Chemical Composition of Bouza and its ingredients", Journal of the Science of Food and Agriculture 24,, p. 1157 
wheat". Lucas and Harris described its manufacture as follows: "It is made by partially baking loaves of coarsely ground grain, generally wheat or barley in Egypt but also millet or sorghum in Nubia. The loaves are then broken up and soaked in water with sprouted grain (malt), a source of enzymes that convert complex carbohydrates to simple sugars, which are then available for fermentation. A new batch may be inoculated ("primed") with the remnants of an old one. The infusion is sometimes heated and sustained at a warm temperature for up to several hours, which can enhance enzyme action without killing the fermenting agents. The mixture is left to ferment for a day or more, its alcoholic content increasing for up to several days. Should it become stronger than desired it is diluted with water". ${ }^{63}$

Hops are not added to $B \bar{u} z a$, so it lacks the bitterness familiar to Europeanstyle beers and ales, instead a variety of fruits or even greens may be added as sources of additional simple sugars for fermentation or as preservatives. Egyptian $B \bar{u} z a$ as well as some other African traditional beers were consumed either sieved or unsieved, this is the reason why some describe them as a beverage while other prefer to call them a thin gruel ${ }^{64}$. Morcos, notes that the caloric and nutritive value of unsieved $B \bar{u} z a$ is greater than that of the sieved variety. It might help to correct some nutritional deficiencies, as the live yeast concentration (in the second-day $B \bar{u} z a$ ) accords a higher protein content than that of bread made from the same wheat, and is also regarded as a supplement of B Vitamins. ${ }^{65}$

It is worth-mentioning that during the reign of the Fatimid Caliph Hakim Biamrillah (early Eleventh Century), he forbade the consumption of beer along with wine, raisins, honey and molokheya. Later on, in the Thirteenth Century, the Mamluk Sultan Beybers also forbade beer, wine and hashish, although the loss of taxes levied on wine hardly helped him to sustain his powerful military activities. ${ }^{66}$

${ }^{63}$ Lucas, A. and J. R. Harris. (1962). Ancient Egyptian Materials and Industries, Fourth Edition, Edward Arnold, London, p. 11.

${ }^{64}$ Geller, J. (1992) "From Prehistory to history: Beer in Egypt", in: Friedman, R. and Adams, B. (eds.). The Followers of Horus: Studies dedicated to Michael Allen Hoffman, Egyptian Studies Association Publication No. 2, Oxbow Monograph 20, p. 19.

${ }^{65}$ Morcos, S. R., S. M. Hegazi and S. T. El-Damhougy. (1973) "Fermented Foods in Common Use in Egypt II. The Chemical Composition of Bouza and its ingredients", Journal of the Science of Food and Agriculture 24, p. 1159-61.

${ }^{66}$ Geller, J. (1992) "From Prehistory to history: Beer in Egypt", in: Friedman, R. and Adams, B. (eds.). The Followers of Horus: Studies dedicated to Michael Allen Hoffman, Egyptian Studies Association Publication No. 2, Oxbow Monograph 20, p. 19-20. 


\section{Egyptian Beverages: A Journey through Ancient to Modern Times}

\section{Contemporary Beer Production Techniques}

The history of alcoholic beverages production in Egypt till almost 1880 could be co-related with $B \bar{u} z a$, as previously mentioned, which is a traditional Turkish beverage that appeared after the Ottomans' arrival to Egypt in 1517. It was defined as "a drink closer to a solid than a liquid, resembling nothing more than cool, slightly fermented farina, with a sort of fizzy tingle imparted by the carbon dioxide, as well as the tell-tale yeasty-sour smell and taste of the stuff leaves little doubt that it contains some, though probably very little alcohol". ${ }^{67}$

The previously mentioned definition focused on the main characteristics of the ancient drink which were semi-solidity, carbonation, and alcoholic nature as it had no standardisation for being produced from barley, sorghum, millet, or any other available ingredient and thus $B \bar{u} z a$ consistency, taste, and alcohol content varied widely from one recipe to another as it had a milk-like appearance. $^{68}$

$B \bar{u} z a$ was the popular drink among the working class and the humble society as it was cheap and alcoholic as it was considered as a food for containing protein, iron, and other nutrients.

Egyptologists have proofed that $b \bar{u} z a$ was similar in its preparation, composition and consumption to beer in ancient Egypt. Consequently, the straw was essential with drinking $B \bar{u} z a$ as it worked as a filter preventing a mouthful of particulates. ${ }^{69}$

$B \bar{u} z a$ was an important part of the Egyptian community, as it was served and enjoyed in their houses for privacy and in social gatherings like shops and taverns but it was not recommended for the upper class and leaders. It was connected to the humble associations thus it was recorded as a short shrift in the history of the Egyptian beverages. The most popular historical stating of $B \bar{u} z a$ is in Edward Lane's seminal 1836 work, An Account of the Manners and Customs of the Modern Egyptians, in which Lane referred to Büza as the beverage of Nile boatmen "and other persons of the lower orders." 70

In the Sixteenth Century, Büza used to have different names that indicated that there were a number of different cereal-based alcoholic drinks without realising their similarities, names like Mizr and Merīssa. For example 'Awn al-Sharif Qasim's dictionary of colloquial Sudanese, summarised Merīssa as

67 Foda, O. D. (2015). Grand Plans in Glass Bottles: The Economic, Social, and Technological History of Beer in Egypt 1880-1970. Unpublished PhD Dissertation, University of Pennsylvania, pp 25-64.

${ }^{68}$ Fuhrmann, M. (2014). "Beer, the Drink of a Changing World:Beer Consumption and Production on the Shores of the Aegean in the 19th Century". Turcica, 45, pp. $79-123$.

${ }^{69}$ Georgeon, F. (2002). "Ottomans and Drinkers: The Consumption of Alcohol in Istanbul in the Nineteenth century", Journal of Turkish Studies, 26, pp. 58-63.

${ }^{70}$ Hattox, R. (2013). Coffee and Coffeehouses: The Origins of a Social Beverage in the Medieval Near East. University of California Press, p. 123. 
" a drink made from an infusion of sorghum or millet... It is steeped in the liquid of the dates or something else and worked by hand until it dissolves into its constituent parts." That method was similar to the preparation of Būzara. ${ }^{71}$

As previously mentioned, $B \bar{u} z a$ was valued as moonshine by the lower classes whether Egyptians or Sudani for its cheapness and also serving it in its unfiltered form made it play the role of a supplier of the different nutrients like fat, protein, carbohydrates, minerals and vitamins which were lacked in the diets of those classes.

Al-Sanhuri efficiently captured the preparation of $B \bar{u} z a$ as grains of durra (sorghum), millet, rice or the like are soaked in a covered hole for around two nights till it sprouted. The sprouts are removed, dried or baked, and crushed up and then there was a paste out of the flour of the grain ready to fermentation. ${ }^{73}$

It is noticeable in its preparation that the main and only components were grain and water. The absence of hops and yeast which are the two key ingredients in the production of the modern beer as will be mentioned later, makes a huge difference between $B \bar{u} z a$ and modern beer. It was concluded that $b \bar{u} z a$ production was distinguished in Egypt from Pharaonic times to the 1880s, (Pharaonic, Hellenistic/Roman, Islamic, and Ottoman) as the culture extended its borders to Sudan. ${ }^{74}$

$B \bar{u} z a$ had to be drunk shortly after production as it lacked the benefits of ageing that was found in beer for the presence of hops that in addition to giving beer its recognised flavour, it acts as a preservative and that was the main reason for its introduction in the recipe from the beginning. ${ }^{75}$

$B \bar{u} z a$ had a different character than beer that appeared in Egypt in the 1880s, simply it contains both hops that provides beer its distinguished flavour and

\footnotetext{
${ }^{71}$ Sikainga, A. A. (2010). Slavery and Social Life in Turco-Egyptian Khartoum in Race and Slavery in the Middle East: Histories of Trans-Saharan Africans in Nineteenth Century Egypt, Sudan, and the Ottoman Mediterranean, American University of Cairo Press, p. 154.

${ }^{72}$ Reynolds, N. Y. (2003). Commodity Communities: Interweavings of Market Cultures, Consumption Practices, and Social Power in Egypt, 1907-1961. PhD dissertation, Stanford University, pp. 16-28.

${ }^{73}$ Al-Sanhuri, M.A. F. (1978). Al-Muskirat. Dar al-Nahda al-Arabiyya, Cairo, p. 46.

${ }^{74}$ Crawford, D. J. (1979). "Food: Tradition and Change in Hellenistic Egypt.", World Archaeology, 11, p. 136.

${ }^{75}$ Manton, E. (2015). "Historical and Cross-cultural Changes in Taxation of Different Alcoholic Beverages.", Foundation for Alcohol Research and Education, pp. 24-33.
} 
yeast which is an important factor in the process of fermentation, that organism is in charge of converting sugars to ethanol and $\mathrm{CO}_{2}{ }^{76}$

Although the pioneers in the alcoholic beverage industry were Europeans the success of that industry returned to the mix of efficient use of local resources eventually served as the base of the modern Egyptian alcoholic beverage industry. This history of beer in Egypt passed through four economic eras, from the Pre-Colonial Era (pre-1880), to the Colonial/Semi-Colonial Era (1880-1930), to the Economic Nationalist Era (1930-1960), and finally to the Arab Socialist Era (1960-1970). ${ }^{77}$

Beer production started by using the imported malted barley, the Egyptian breweries started the process, which included crushing, mashing, boiling, lautering, cooling, fermenting (brewing), and storing. First, crushing the malted barley separated the outside of the barley, then, mashing broke down the starch in the barley into fermentable sugars. After mashing, lautering removed the husks of the malted barley separated out by crushing. This step was very important as it highlighted one of the major differences between beer and $B \bar{u} z a$, as the husk was what gave $B \bar{u} z a$ its gruel-like texture. Then the sugary mixture known as wort, was then boiled for around an hour and then hops was added. ${ }^{78}$

Addition of hops to the wort was another major difference between beer and $b \bar{u} z a$, and it had a significant impact on the beer's distinctive bitterness taste and extending its shelf life and then adding the yeast, as choosing a good strain had a significant impact on the beer. The breweries had to cool the product to a temperature of either $7^{\circ} \mathrm{C}\left(40^{\circ} \mathrm{F}\right)$ or $15^{\circ} \mathrm{C}\left(60^{\circ} \mathrm{F}\right)$ as the temperature also had a significant impact on the product. Simply, beer is the result of the fermentation of especially barley, corn, rye, wheat, or blend of several grains in addition to yeast and usually flavoured with hops. It contains 4-8\% alcohol and its energy value ranges between 28 and $73 \mathrm{kcal}$ per $100 \mathrm{ml}$. Finalisation of the product required the injection of $\mathrm{CO}_{2}$ in barrels or cans. ${ }^{79}$

\footnotetext{
${ }^{76}$ Aynur, H. and Schmidt, J. (2007). "A Debate between Opium, Berş, Hasish, Boza, Wine and Coffee." Journal of Turkish Studies, 31, p. 53. Also Morcos, S. R., S. M. Hegazi and S. T. El-Damhougy. (1973) "Fermented Foods in Common Use in Egypt II. The Chemical Composition of Bouza and its ingredients", Journal of the Science of Food and Agriculture 24, p. 1160.

${ }^{77}$ Reynolds, N. Y. (2012). A City Consumed: Urban Commerce, the Cairo Fire, and the Politics of Decolonization in Egypt, Stanford University Press, pp. 84-93.

${ }^{78}$ Alba-Lois, L. and Kischinevzky, S. (2010). "Beer \& Wine Makers.", Nature Education, 3(9), p.17.

${ }_{79}$ Lyumugabe, F., Gros, J., Nzungize, J., Bajyana, E., and Thonart, P. (2012). "Characteristics of African Traditional Beers Brewed with Sorghum Malt: A Review.", International Journal of Food Microbiol. 132, pp. 509-530. Also Mayo, B., Ammor, M. S., Delgado, S., and Alegría, A. (2010). Fermented Foods and Beverages of the World. CRC Press, Taylor and Francis Group, pp. 263-288.
} 
Focusing on the Egyptian beverage industry since Pharaonic times till the Nineteenth- and Twentieth centuries, a mixture of foreign ideas and concepts for example brewing and distilling, refrigeration, and transport with the traditional and cultural taste same as the Egyptian environment, plentiful water sources, inexpensive labor and huge population. ${ }^{80}$

Louis Pasteur in the 1860s discovered the important role of the cells of yeast in alcohol formation, his discovery went beyond in the process of beer fermentation as brewers had optimal control on the brewing process. ${ }^{81} \mathrm{He}$ concluded that spoilage of beverages as wine, beer and milk were resulted from the presence of micro-organisms which went in during whether production or storing processes, so he developed the pasteurisation method that is defined as " heating a beverage to a certain temperature in order to remove the unwanted microorganisms that caused spoilage and illness. ${ }^{82}$

In 1897, a group of Belgian investors built a factory in the Ibrahimia District of Alexandria, where the Crown and Pyramid breweries were founded. The imported malted barley from Czechoslovakia was firstly crushed in order to take off the outside of the barley then mashed to break down the starch to fermentable sugar. ${ }^{83}$

The years 1897 and 1898 were turning point in the history of beer in Egypt. That was when a set of Belgian capitalists established Crown Brewery in Alexandria and Pyramid Brewery in Cairo facing local and foreign competitors.. During the pre-World War I period, the two breweries resisted among Greeks, Italians, Britons, and others who had come to Egypt looking for new economic opportunities especially after the opening of the Suez Canal in 1869, to build up their clientele. Those Europeans had a fundamental role that "total control brewing" allows them to solve any problem in Egypt, as that industry only succeeded after it had adjusted itself to the environment of Egypt. Standardisation, efficiency, and reproducibility

\footnotetext{
${ }^{80}$ Homan, M. (2004). "Beer and Its Drinkers: An Ancient Near Eastern Love Story.", Near Eastern Archaeology, 67, pp. 85-86. Also Lane, E. W. (2003). An Account of the Manners and of the Customs of the Modern Egyptians. American University of Cairo Press, p. 335.

${ }^{81}$ Manton, E. (2015). "Historical and cross-cultural changes in taxation of different alcoholic beverages.", Foundation for Alcohol Research and Education, pp. 24-33. Also Hayashida, F. M. (2008). "Ancient Beer and Modern Brewers: Ethno-archaeological Observations of Chicha Production in Two Regions of the North Coast of Peru.", Archaeol. 27, pp. 161-174

${ }^{82}$ Dolci, P., Alessandria, V., Rantsiou, K., and Cocolin, L. (2015). "Advanced Methods for the Identification, Enumeration, and Characterization of Microorganisms in Fermented Foods.", Advances in Fermented Foods and Beverages. Elsevier, pp. 157-176.

${ }^{83}$ Fonder, N. (2013). Pleasure, Leisure, or Vice? Public Morality in Imperial Cairo, 1882 1949. PhD Dissertation. Harvard University, pp. 4-10.
} 
with the local advantages of the Egyptian market: primarily inexpensive labor, plentiful water, a hot and dry climate, and a thirsty population that was willing for a refrigerated product. ${ }^{84}$

Stella and Egypt have always been connected together, if not through its recognised green bottle it can be recalled from the presence of the different related stuff such as coaster, mug, ashtray or flyers. That is the case in Egypt, Stella is widely known among Egyptians whether being consumed or not for religious or personal taste reasons. ${ }^{8}$

Stella's beginnings was in the 1920s, as a joint Pyramid and Crown venture, and it took only thirty years to become the dominant local brand and achieved the crucial goal of any brand and had a cultural penetration. Stella is the beer of Egypt, the popular drink among young Egyptians need to have fun, in other words leisure culture. ${ }^{86}$

The period between 1923 to 1935 , beer consumption was significant among foreign soldiers, educated middle class and elite Egyptians. Stella advertisements which highlighted the healthful beer's aspects resulted in increasing the consumption patterns but the Islamophobic movement produced a powerful quarrel against beer. ${ }^{87}$

Nowadays Heineken Brewing Company is considered one of the major players in the Egyptian beverage industry, it actually started since the 1930s as a main stockholder in the biggest two Egyptian beer companies, Al-Ahram (Pyramid) Brewery and Crown Brewery. The business was terminated in 1963 when the Egyptian government nationalized these companies, after four decades, actually in 2003, Heineken returned back and acquired al-Ahram Beverage Company the replacement of the Pyramid and Crown Breweries. ${ }^{88}$ The history of beer in Egypt had an important social, cultural, economic and political extents that were linked to the Egyptian identity among people and organisations. Alexandria and Cairo are the basis of all later beer-selling operations in Egypt. However, the most important and most worldwide of the

\footnotetext{
${ }^{84}$ Reynolds, N. Y. (2012). A City Consumed: Urban Commerce, the Cairo Fire, and the Politics of Decolonization in Egypt. Stanford University Press, pp. 84-93. Also Sikainga, A. A. (2010). Slavery and Social Life in Turco-Egyptian Khartoum in Race and Slavery in the Middle East: Histories of Trans-Saharan Africans in Nineteenth Century Egypt, Sudan, and the Ottoman Mediterranean, American University of Cairo Press, p. 154.

${ }^{85}$ Reynolds, N. Y. (2012). A City Consumed: Urban Commerce, the Cairo Fire, and the Politics of Decolonization in Egypt. Stanford University Press, pp. 84-93.

${ }^{86}$ Tignor, R. L. (1984). State, Private Enterprise and Economic Change in Egypt, 1918 1952. Princeton University Press, p. 184.

${ }^{87}$ Reynolds, N. Y. (2012). A City Consumed: Urban Commerce, the Cairo Fire, and the Politics of Decolonization in Egypt. Stanford University Press, pp. 84-93. Also Kutyauripo, J., Parawira, W., Tinofa, S., Kudita, I., and Ndengu, C. (2009). "Investigation of Shelf-life Extension of Sorghum Beer (Chibuku) byRemoving the Second Conversion of Malt.", International Journal of Food Microbiol. 129, pp. 271-276.

${ }^{88}$ Hornsey SI. (2012). Brewing. Cambridge: Royal Society of Chemistry, pp. 221-2.
} 
players into the Egyptian beer business was Heineken. Its highest techniques of brewing had added Egypt to its growing multinational beer empire. So it was noticed the interaction between "total control brewing" and the reality of the Egyptian environment. ${ }^{89}$

During the Twenty-first Century, many attempts have been made to re-inact the ancient Egyptian beer. A trial was noted in 1996 by Dr Delwn Samuel, Cambridge University, with the Scottish and New Castle Breweries. Barry Kemp with his team were investigating beer brewing as per finds from the workmen's village at Deir el Medina, where they found residue in some pottery jars. They isolated several ingredients especially barley or emmer, together with other flavouring herbs. Ultimately a beer was reconstructed and produced carrying the name of Tutankhamun's Ale. The first bottle was sold for an astounding \$ 7686 in 1996 and later sold in Harrods for about $£ 50$ a bottle $^{90}$. In 2011, a more recent attempt to brew beer following the ancient methods was conducted by the Bio-molecular Archaeologist at the University of Pennsylvania Museum, Patrick McGovern in collaboration with an American ale company known as "Dogfish Head Craft Brewery". They managed to produce a beer, a similar as possible to the ancient Egyptian beer. They even named it: "Ta Henket". ${ }^{91}$ (Fig 6 shows the label)

\section{Wine:}

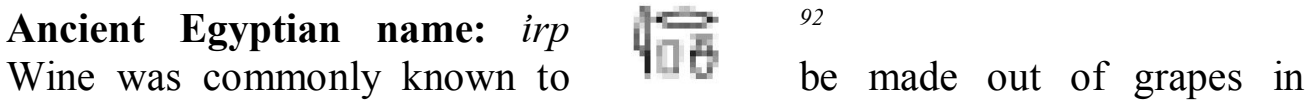
ancient Egypt. However, wine was also made out of dates, pomegranates, courgettes, figs, etc... as will be discussed later.

${ }^{89}$ Mahgoub, S., A. (2018). Fermented Food in Egypt: A Sustainable Bio-preservation to Improve the Safety of Food. PhD dissertation. Zagazig University, Egypt, pp. 33-59.

${ }^{90}$ Dickinson, S. "Reconstructing the Ale of Ancient Egypt", http://www.worldofbeer.co.za/news/reconstructing-the-ale-of-ancient-egypt. Accessed on $10 / 11 / 2018$

${ }^{91}$ For more information about the trial, refer to the article of Daniel Fromson in the Washington Post published on 23rd of November 2011. https://www.washingtonpost.com/lifestyle/food/historic-brews-being-poured-oncemore/2011/11/23/gIQAEHNA9N_story.html?noredirect=on\&utm_term=.4b6b5e79aa7c.

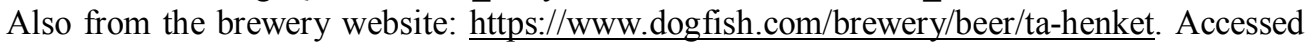
on $10 / 11 / 2018$

${ }^{92} \mathrm{~Wb}$ I, 11

Hieroglyphs: Rosmorduc, Serge. (2014). JSesh Documentation. [online] Available at: http://jseshdoc.qenherkhopeshef.org [Accessed 26 Dec. 2018]. 


\section{Egyptian Beverages: A Journey through Ancient to Modern Times}

\section{Mythology}

Hathor had a special connection with wine. She was often referred to as "Lady of Drunkenness". A special festival for "the Drunkenness of Hathor" was celebrated at Dendera. ${ }^{9}$

Osiris, long before being a god, was a ruling king. He was thought to be the first man to drink wine and showed his people how to plant vines to provide grapes for this remarkable new beverage, as beer was thought to be a forerunner. He was also the one who, earlier, was responsible for teaching them how to make beer from barley. ${ }^{94}$ According to the Pyramid Texts, Osiris was nominated as "Lord of the Wine" was that the annual flood of the Nile was considered as the seasonal revival of vegetation in general, and vine in particular. Moreover, the colour of wine was linked with the Nile flood, as it showed a similar hue to the mudrich waters that flowed from the source of the Nile south in Atbara, during the flood season. ${ }^{96}$

However, according to Diodorus, Dionysus was the inventor of wine. "....... and the discovery of the vine, they say, was made by him Dionysus near Nysa, and that, having further devised the proper treatment of its fruit, he was the first to drink wine and taught mankind to large the culture of the vine and the use of wine, as well as the way to harvest the grape and to store the wine...." ${ }^{97}$ Nevertheless, Dionysus has long been assimilated with Osiris, as per his connection with agriculture. ${ }^{98}$

Nonetheless, the hieroglyph for the wine-press $\check{s} s m . w$ is attested as early as the Pyramid age,i.e. mentioned in the Pyramid Texts ${ }^{99}$.

Shesmu šsm.w ${ }^{100}$ was "the god of the Wine, of the oilpress and of cellars". An interesting link between Shesmu

${ }^{93}$ Poo, M.-C. (2001) "Wine", in Redford, D.B. (ed): The Oxford Encyclopaedia of Ancient Egypt, Vol 3, Oxford University Press, p. 502.

${ }^{94}$ Armour, R. A. (2001) Gods and Myths of Ancient Egypt, second edition, The American University in Cairo Press, Cairo, p. 55

${ }^{95}$ Utterance no 442 on the West Wall of the Sarcophagus chamber of the Pyramid of Pepi I. Lichtheim, M.(1975) Ancient Egyptian Literature, Vol I: The Old and Middle Kingdoms, University of California Press, p. 45

${ }^{96}$ Poo, M.-C. ( 2001)“Wine", in Redford, D.B. (ed): The Oxford Encyclopaedia of Ancient Egypt, Vol 3, Oxford University Press, p. 502.

${ }^{97}$ Diodorus., I, 15, 8. Diodorus Siculus (1933-1967). Library of History, Translated by C.H. Oldfather, C. Sherman, C.B. Welles, R.M. Geer and F.R. Walton, 12 Vols, New York: G.P. Putnam's Sons.

${ }^{98}$ Ghalioungui,P., Darby, W. and Grivetti, L. (1977) Food: Gift of Osiris, Vol 2, Academic Press, London, p. 555

${ }^{99}$ Utterances no 273 - 274 on the East Wall of the antechamber of the Pyramid of Unas. Lichtheim, M. (1975) Ancient Egyptian Literature, Vol I: The Old and Middle Kingdoms, University of California Press, p. 37-38.

${ }^{100} \mathrm{~Wb}$ IV, 537. 
and assumption that the colour of wine was red is explained by Poo as follows: "Mythological and literary allusions indicate that the colour of wine was considered red. The wine-press god Shesmu for example was depicted as a slaughterer who pressed human heads in the wine press. Undoubtedly, this was an allusion to a scene where grapes juice was extracted from the wine press, and the red juice was linked to human blood". ${ }^{101}$

\section{History}

It is worth mentioning that the term irp specifically refers to grape-based wine., which already existed in ancient Egypt since the Predynastic Era. This is proved by the recovery of wine jars found in sites of this particular era. ${ }^{102}$ As early as the First dynasty; Den called his vineyard "The Enclosure of the Beverage of the Body of Horus". Khasekhemwy, last king of the Second dynasty, named his "Praised be the souls of Horus". Zoser, founder of the Third dynasty, called it "Praised Horus who is in the Front of Heaven". ${ }^{103}$

Around 700 jars were recovered from tomb no (U-j) at Abydos, dating back to around $3150 \mathrm{BC}$ (probably Scorpion King). If each one of those jars were filled with wine, the capacity would have mounted up to 1,200 gallons, which is a pretty big amount. This could be regarded as an evidence of the presence of wine-making industry since the early ages, also it refers to the importance of wine as a beverage, whether in the ancient Egyptian's daily life or the afterlife. ${ }^{104}$

Emery discovered many sealed jars of (evaporated) wine among the remains of a meal in a second dynasty tomb. ${ }^{105}$ Wine-making scenes ${ }^{106}$ cover the walls of most tombs form the Old Kingdom, at Saqqara and Giza, as well as, tombs of the Middle and New Kingdoms, which add more depth and colour

Hieroglyphs: Rosmorduc, Serge. (2014). JSesh Documentation. [online] Available at: http://jseshdoc.qenherkhopeshef.org [Accessed 26 Dec. 2018].

${ }^{101}$ Poo, M.-C. (2001) "Wine", in Redford, D.B. (ed): The Oxford Encyclopaedia of Ancient Egypt, Vol 3, Oxford University Press, p. 502.

${ }_{102}$ Poo, M.-C. (2001) "Wine", in Redford, D.B. (ed): The Oxford Encyclopaedia of Ancient Egypt, Vol 3, Oxford University Press, p. 502.

${ }^{103}$ Ghalioungui,P., Darby, W. and Grivetti, L. (1977) Food: Gift of Osiris, Vol 2, Academic Press, London, p. 555-6

${ }^{104}$ McGovern, P. (July/August1998)“Wine for Eternity”, Archaeology, Vol 15, No 4, p. 28-9.

105 Emery, W. B. (1962) A Funerary Repast in an Egyptian Tomb of the Archaic Period. Leiden: Nederlands Institut voor het Nabije Osten.

${ }^{106}$ It is said that these wine-making scenes were intended to supply the deceased with plenty of wine to cover at least eternity, upon recitation of certain spells or religious formulae. 
to the production. ${ }^{107}$ Most vineyards were located in the Nile Delta and the oases. Wine containers (amphorae) have been recovered in settlement sites such as Tell El Amarna and Malqata, most probably used as tomb offerings. ${ }^{108}$

Although Egyptians produced wine from locally grown vineyards dotted around the Egyptian lands from lower and upper Egypt, it also held a high place on the list of imports due to its high consumption. It was mainly imported from Greece, Syria and Palestine. ${ }^{109}$

\section{Ancient Wine-making Techniques}

As for manufacturing techniques, Montet wrote that the grapes were individually picked, which could be considered as a laborious and timeconsuming act, although this might be practised for some high quality wines. ${ }^{110}$ Grapes are then transferred in baskets to the treading vats, of which unfortunately, none survived, although they are illustrated in most of the scenes. The grapes are then squeezed by treading, as still practiced in some wineries in Europe. In some scenes, the workers are shown maintaining their balance while treading the slippery plane by holding onto ropes hanging from the ceiling using a cross-beam that forms a frame with two vertical poles attached at each end of the vat. In other cases, the workers take support on each others' hips, the first and last of the row leaning on two sticks outside the vat. Occasionally, the act is accompanied by music and the clapping of the people watching.

After tredding, the remaining fruits were transferred to a cloth bag for extra squeezing. In one technique, one end of the bag was tied to a fixed support, and the other end was fixed to a pole which was twisted by several men. Expressing the juice of grapes in a bag tied at one end, and twisted at the other. In another, both ends of the bag were tied to poles, and the two groups of men wrung the bag by turning the poles in opposite directions In between the two groups, a man was busy with hands and feet keeping the poles apart. In a similar, more humorous scene, this man is replaced by a baboon ${ }^{112}$. The

${ }^{107}$ Ghalioungui,P., Darby, W. and Grivetti, L. (1977) Food: Gift of Osiris, Vol 2, Academic Press, London, p. 556.

${ }^{108}$ Ikram, S. (2001) "Diet", in Redford, D.B. (ed): The Oxford Encyclopaedia of Ancient Egypt, Vol 1, Oxford University Press, p. 392.

${ }^{109}$ Ghalioungui,P., Darby, W. and Grivetti, (1977) L. Food: Gift of Osiris, Vol 2, Academic Press, London, p. 597-612

${ }^{110}$ Montet, P. (1958) Everyday Life in Egypt in the Days of Ramesses the Great. Translated by A.R. Maxwell-Hyslop and M.S. Drower. London: Edward Arnold, p.106

${ }^{111}$ Ghalioungui,P., Darby, W. and Grivetti, L. (1977) Food: Gift of Osiris, Vol 2, Academic Press, London, p. 560.

112 The artist, no doubt a humorist, replaced the man holding the poles apart with a big baboon. Tomb of Nefer. Saqqara. Old Kingdom. Moussa, A. M. and Altenmuller, H. (1971) The Tomb of Nefer and Ka-Hay, Mainz-am-Rhein: P. von Zabern. 
aforementioned method of pressing was particularly practised in Lower Egypt, while wine-pressing in Upper Egypt was normally performed by pressing with bare feet. ${ }^{113}$

The extracted juice was then strained through cloth into fermentation jars. In some cases the process was quickened by warming; and when it was over, the product was poured gradually into special containers, which were small and circular for religious of funerary use, larger for domestic consumption. ${ }^{114}$

Some scholars such as Lutz, for instance, believed that the inside of the jars was coated with a layer of an impermeable substance such as bitumen or resin. ${ }^{115}$ This habit could have survived since the start of wine-making when they used to keep it in leather bags so the had to insulate the bags by means of resin. It seems that the acquired taste appealed to the Egyptians so they kept on using the same technique even after starting to use earthenware jars for keeping the wine. ${ }^{116}$ However, other Egyptologists, such as Montet, have argued that the description of Egyptian wine as "very sweet" and "tends to spoil early" as described by Strabo $(17,1,35)$ disagrees with the former assumption. Especially that the heavily resinated Greek wines were said to withstand better the acidic change because of the coating. ${ }^{117}$ Lucas, also, confirmed this conclusion for, in the large number of wine jars that he examined, he found no evidence of coating before the Greek period. ${ }^{118}$

Finally, when the fermentation period was over, the wine vessels were sealed with a lid of straw and clay, in which the official stamps were impressed, with the year of the king's rule, the district, the name of the wine and, sometimes the name of the gardener. ${ }^{119}$ In many of the jars, safety holes were drilled either in the stopper caps or the necks, to prevent bursting by accumulation of gases. These were plugged by straw or wax, or with a plug of clay stamped with the owner's seal e.g. one of the wine jars recovered from the tomb of Tutankhamen. Under normal conditions and at room

\footnotetext{
${ }^{113}$ Wilkinson, J. G. (1854) Manners and Customs of the Egyptians, London, Vol 2, p. 152-5

${ }^{114}$ Ghalioungui,P., Darby, W. and Grivetti, L. (1977 ) Food: Gift of Osiris, Vol 2, Academic Press, London, p. 560-1

${ }^{115}$ Lutz, H. F. (1922) Viticulture and Brewing. Leipzig: Hinrichs, p. 56-7.

${ }^{116}$ Wilkinson, J. G. (1854) Manners and Customs of the ancient Egyptians, Vol 2, London, p. 158

${ }^{117}$ Montet, P. (1958) Everyday Life in Egypt in the Days of Ramesses the Great. Translated by A.R. Maxwell-Hyslop and M.S. Drower. London: Edward Arnold, p.88

${ }^{118}$ Lucas, A. (1962) Ancient Egyptian Materials and Industries. 4th edition. Edited by J.R. Harris. London: Edward Arnold, p. 20

${ }^{119}$ Kees, H. (1961) Ancient Egypt. A Cultural Topography. Translated by Ian F. E. Morrow. Edited by T.G.H. James. London: Faber and Faber, p. 82.
} 
temperature, the natural yeast formed on grape skins quickly ferments juice to wine. Slow-pressing methods, practiced by the ancient Egyptian, combined with the hot weather contributed to the rapid fermentation, which probably even began before the juice went into jars. Jars were then sealed with clay sealings with rim and string impressions, pressed onto leather or cloth covers tied over the mouths with string. These covers would have been particularly suitable for a young wine, from which fermentation gases still need to be released. ${ }^{120}$

Flavourings were known to be added to wine, for example, from the tomb no (U-j) at Abydos, dating back to around 3150 BC (probably Scorpion King), 47 jars contained grape pips and several complete grapes. Also 11 vessels had remains of sliced figs, which had been perforated, strung together and probably hung in the liquid. Both whole grapes and figs are thought to have been used to sweeten or add flavour the wine. ${ }^{121}$

The colour of grapes ranged in ancient Egyptian illustrations from white, through pink, green, red, blue and black. Similarly, we can assume that there was a variety of colours used for wine, but could not be confirmed. There is a mention of "irp ďs r" which means red wine but, the word desher could be interpreted in different ways. ${ }^{122}$ Wine was available in Egypt within different varieties e.g date wine ${ }^{123}$, palm wine ${ }^{124}$, fig wine ${ }^{125}$, pomegranate wine ${ }^{126}$.

There is evidence that vintages (type and year of production) were marked on the jar or on the seal, bearing the name of the vineyard owner and the vineyard of origin. The quality of wine was also indicated on the label. Descriptive terms like "good", "very good", or "very very good" were found on the jars from Malta, Tell el Amarna and the tomb of Tutankhamen (KV 62). The date of production was also recorded, this piece of information is particularly important, since Egyptian wine did not endure/last for long and had to be consumed within a year of production. ${ }^{127}$ It had been suggested that, at some point of the final stage of processing, wine was tasted and its quality assessed. $^{128}$

\footnotetext{
${ }^{120}$ McGovern, P. (July/August 1998) "Wine for Eternity”, Archaeology, Vol 15, No 4, p. 29.

${ }^{121}$ McGovern, P. (July/August 1998) "Wine for Eternity", Archaeology, Vol 15, No 4, p. 29.

${ }^{122}$ Ghalioungui,P., Darby, W. and Grivetti, L.(1977) Food: Gift of Osiris, Vol 2, Academic Press, London, p. 556-7.

${ }^{123}$ Ebers Papyrus, X, 28. After Grapow and Westendorf (1958,) Vol. IV, 1, p. 121

${ }^{124}$ Herodotus (II, 86), Diodorus $(1,91,5)$

${ }^{125}$ Pyramid Texts (Pyr., 146a, T117a, N454a, Pepi II) and Papyrus Anastase $(3,3,5)$

${ }^{126}$ Pliny (XIV, XIX, 103), Dioscorides (V, 34), Song of Solomon $(8,2)$

${ }^{127}$ Ikram, S. (2001) "Diet", in Redford, D.B. (ed): The Oxford Encyclopaedia of Ancient Egypt, Vol 1, Oxford University Press, p. 392.

${ }_{128}$ Athenaeus, The Deipnosophists (i.e., The Learned Banqueters). http://digicoll.library.wisc.edu/cgi-bin/Literature/Literature-

idx?type=turn\&entity $=$ Literature. AthV1.p0062\&id=Literature.AthV1\&isize $=$ M\&pview=hid e. Accessed on 20/11/2018
} 
The best wine known was the Teniotic, which was produced in a place called Tenia. Its colour was pale and white, and it boosted a degree of richness that it was often mixed with water to be diluted. ${ }^{129}$ Next in line in quality and popularity was the Mareotis. According to Athenaeus, "The Mareotic grape was remarkable for its sweetness" and the wine is described by him as, "Its colour is white, its quality excellent, and it is sweet and light, with a fragrant bouquet; it is by no means astringent, nor does it affect the head."130

\section{Modern and Contemporary Wine-making Techniques}

During the period between 1798 and 1801, accompanying Napoleon expedition to Egypt, there was an introduction to both araq and wine. Araq was a liquor made from dates which are emerged in water for forty days in winter, and for ten to fifteen in the summer then mixed with anise and boiled then the distillation process. It is white in colour and the anise flavour is very well distinguished.

Wine is a beverage which is popular to the French, so normally it was known then in Egypt, it was prepared simply as "Having trod the grapes for one hour in a jar of cylindrical earth in the shape of a small chest, they are put into a large bag made of a very thick woolen cloth, which is wrung out and the juice of the grapes is placed into another jar that is similar to the first. The liquid is then allowed to ferment for eight to fifteen days. The liquid is then transferred to one of those great amphorae, which are used to transport oils of the Berbers, and this earthenware vase is buried almost to the neck and closed with a wooden plug sealed with plaster." Regardless this precaution, the wine was expired in a few months the case as in an ordinary vinegar. $^{132}$

Fruits are vital for the humans' diet as they are full of vitamins and minerals that are essential for their overall health. Wines are made from different types of fruits such as grapes, peaches, plums or apricots, banana, berries...etc but the most common is from grapes as for its natural chemical balance of the

\footnotetext{
${ }^{129}$ Ghalioungui,P., Darby, W. and Grivetti, L. (1977) Food: Gift of Osiris, Vol 2, Academic Press, London, p. 556-7

${ }^{130}$ Romant, B. (1986 )(translated by J. Smith). Life in Egypt in Ancient Times, Editions Minerva, S.A. Geneve, p. 63-64.

131 Foda, O. D. (2015). Grand Plans in Glass Bottles: The Economic, Social, and Technological History of Beer in Egypt 1880-1970. Unpublished PhD dissertation, University of Pennsylvania, pp. 25-64.

${ }^{132}$ Saranraj, P., Sivasakthivelan, P. and Naveen, M. (2017). "Fermentation of Fruit Wine and its Quality Analysis: A Review”. Australian Journal of Science and Technology, 1(2), pp. 85-97.
} 
grape juice which helps in the fermentation process with no need to add sugars, acids, enzymes, or any other nutrients then they pass the process of fermentation and ageing. ${ }^{133}$

In the early ages of wine production, wine producers traditionally used their feet to crush and soften the grapes before leaving the mixture to be stored in buckets. Doing this, they relocated microorganisms from their feet to the grapes' mixture. At that time, no one knew that the secret behind alcohol production during fermentation was because of one of these microorganisms, a tiny, one-celled eukaryotic fungus that is undistinguishable by the bare eye: yeast. It took more than hundreds of years before the science revolution and researchers observe these microorganisms by microscopes. ${ }^{134}$

Wines are undistilled alcoholic beverages with an alcohol content which ranges between 10 and $14 \%$ and $2-3 \%$ sugar with energy value ranging between 70 and $90 \mathrm{kcal}$ per $100 \mathrm{ml}$ as the fermentation process increases both the nutritional value as it freedoms the amino acids and the other nutrients and the sensory qualities, especially flavour. ${ }^{135}$

Wines come out in different colours (red, white, and rose) and have several types, which dry and sweet, still and sparkling, and wines fortified with grape spirit (brandy). That gave the chance for the product to be served in a large scale of individual tastes, go along with different dishes and in diverse life occasions and events from birth to death due to its purifier and profound mind-altering effects . ${ }^{136}$

Industrial fermentation procedures are directed with chosen microorganisms under certain conditions with carefully known nutrient concentrations. In other words, nourishing sugars and nutrients in a solution with yeast and the result will be carbon dioxide gas and alcohol. The products of fermentation are as follows: Alcohol, glycerol, and carbon dioxide are obtained from yeast fermentation of various sugars; Butyl alcohol, acetone, lactic acid, monosodium glutamate, and acetic acid are products of bacteria action; and citric acid, gluconic acid, antibiotics, Vitamin B12, and riboflavin are some of the products obtained from mould fermentation. ${ }^{137}$

${ }^{133}$ Adams, M. R. (2010). "Fermented Meat Products", in: Fermented Foods and Beverages of the World. CRC Press, Taylor and Francis Group, pp. 309-322.

${ }_{134}$ Tamang, J. P., Watanabe, K. and Holzapfel, H.(2016). "Review: Diversity of Microorganisms in Global Fermented Foods and Beverages.", Frontiers in Microbiology, 7 (377), pp. 1-28.

135 Jacobs, J. (2006). "Ethanol from Sugar: What are the Prospects for US Sugar Crops?", Rural Cooperatives, 73(5), pp. 23-34.

${ }^{136}$ Plaza E., Munoz R., Roca J., Cutillas A. and Fernandez J. (2015). "Phenolic Compounds and Color Stability of Red Wines: Effect of Skin Maceration Time.", International Journal of Food Microbiol, 135, pp. 266-70.

137 Bokulich, N.A. (2014) "Microbial Biogeography of Wine Grapes is Conditioned by Cultivar, Vintage, and Climate.", Journal of National Acadamic Science, 111, pp.139-148. 
Different yeasts end to different results and to different tolerance levels. Fermentation process extends the shelf life of the final products as it declines the need for any form of food preservation technology such as refrigeration, thus suitable technique for developing countries and remote areas where availability of refined equipment is inadequate. Fermented fruit wines are commonly consumed worldwide as it shares as an important role in the diet of millions of people. ${ }^{138}$

Fermentation can be done in stainless steel tanks, which is popular with many white wines, inside a wooden wine barrel or inside the wine bottle itself as in the manufacture of many sparkling wines like champagne for example.The method of winemaking or actually wine fermentation is one of the most ancient human experiences as it is known since the dawn of civilisation. ${ }^{139}$ Winemaking contains generally three categories of operations, namely, prefermentation, fermentation, and post-fermentation processes. In the case of wines made from grapes, pre-fermentation includes crushing the fruit and freeing juice. In case of white wine, juice is parted from the skin, whereas in red wine, the skins, pulp, and seeds of grapes are kept together and not separated from the juice as it contains the colour and flavour so in order to be extracted in the juice itself. Then, the selected yeast is added to the juice to start the fermentation process. ${ }^{140}$

It is concluded that the major difference between red and white wines is the early subtraction of grape skins in white wine production. The distinguished flavour of grape wine originates from the grapes as raw material give the final product the unique fruity character.

White wine is fermented between $64^{\circ} \mathrm{F}$ and $68^{\circ} \mathrm{F}\left(18^{\circ} \mathrm{C}-20^{\circ} \mathrm{C}\right)$ the most popular Egyptian white wine is called "bosolay" while the red wine is typically fermented at higher temperatures up to $85^{\circ} \mathrm{F}\left(29^{\circ} \mathrm{C}\right) .{ }^{141}$

${ }^{138}$ Freidberg, S. (2009). A Perishable History : Machines are Frozen Spirit. Cambridge: Harvard University Press, pp. 26-35. Also McGovern, P. E. (2009). Uncorking the Past: The Quest for Wine, Beer, and Other Alcoholic Beverages. University of California Press, pp. 96-103. Also Pretorius I. and Hoj P. (2005). "Grape and Wine Biotechnology: Challenges, Opportunities and Potential Benefits.", Aust J Grape Wine Res ,11, pp. 83-108.

139 Bartowsky, E. (2017). "Microbiology of winemaking.", Microbiology Australia, 16, pp. 76-79.

${ }^{140}$ Robinson J. (2016). The Oxford Companion to Wine. 3rd ed. USA: Oxford University Press, pp. 779-87. Also Bokulich, N.A. (2016). "Associations among Wine Grape Microbiome, Metabolome, and Fermentation Behavior Suggest Microbial Contribution to Regional Wine Characteristics.", Journal of National Academic Science, 113, pp. 59-71.

${ }^{141}$ Kunkee R.E., and Vilas M. R. (2014). "Towards the Understanding of the Relationship between Yeast Strains and Flavour Production during Vinification: Flavour Effect in 
After fermentation was accomplished, the wine is filtered by using fining agents such as gelatin, pectin, or casein which are mixed with the wine. The wine was then pasteurised at $50^{\circ} \mathrm{C}-60^{\circ} \mathrm{C}$. The temperature should be controlled, so as not to heat it to above $60^{\circ} \mathrm{C}$, since its alcohol content would evaporate at a temperature of $75^{\circ} \mathrm{C}-78^{\circ} \mathrm{C}$. It is then stored in the different containers which have been mentioned earlier in order to be ready for the ageing process to get rid of undesirable traces and for enhancing the taste, aroma, and preservative properties of the wine. ${ }^{142}$

Early in the Nineteenth Century, for the sparkling wines, they were made in one of three ways: through the injection of wines with carbon dioxide under pressure but unluckily, the sparkle of these wines quickly vanishes, and the product was considered low-grade to the other two sparkling wines one by adding sugar to the wine so the carbon dioxide produced by fermentation of the added sugar gives the wine its sparkle or the original champagne method, is by adding grape juice which contains sugar with other juice components which will helps in enhancing the wine characteristics in closed strong bottles or tanks of special specifications in order to bare the pressure of the refermentation process. ${ }^{143}$

Although sugar is the key component for fermentation, to produce ethanol, lactic acid, and carbon dioxide the higher sugar concentration stops the growth of microorganisms. Most yeast strains can allow an alcohol concentration of $10-15 \%$ before being killed. This is the reason that the percentage of alcohol in wines and beers is classically in this concentration range. ${ }^{144}$

Nowadays, brewers and wine makers can choose different strains of yeast to produce different contents of alcohol which can exceed the limit of even 20 percent of alcohol by volume, as higher concentrations of alcohol (like liquors), the fermented products must be distilled. ${ }^{145}$

Today's wines, however, are not weak; their alcoholic content is increased artificially. According to average ancient dilution ratios, modern wine is

Vinification of a Nondistinct Variety of Grape by Several Strains of Wine Yeast.", International Journal of Food Microbiol 134, pp. 46-50.

${ }^{142}$ Audu, J. (2010). "Comparative Studies of Wine Produced by Spontaneous and Controlled Fermentation of Preserved Cashew.",.Journal of Biological Science, 5, pp. 460-4.

${ }^{143}$ Chilaka C.A., Uchechukwu, N., Obidiegwu, J. and Akpor O. (2017). "Evaluation of the Efficiency of Yeast Isolates from Palm Wine in Diverse Fruit Wine Production.", African Journal of Food Science, 4, pp. 764-74.

${ }^{144}$ Swiegers, J.H. (2005). "Yeast and Bacterial Modulation of Wine Aroma and Flavour.", Aust. J. Grape Wine Res. 11, 139-173.

145 Barrett, D.M. and Lloyd B. (2012). "Advanced Preservation Methods and Nutrient Retention in Fruits and Vegetables.", Journal of Science Food Agriculture, 92, pp. 7-22. 
easily five to ten times stronger in its alcoholic content, even the modern beer is stronger than the ancient wine. ${ }^{146}$

Another dissimilarity is that ancient wine drinking was characterised by limitation and wisdom, while modern drinking is characterised by excess and drunkenness. ${ }^{147}$

In 1928, Ganklies beverage company was founded in Alexandria and it was nationalised in 1952, Heinken bought it in 2002. Egypt is the 57th-largest wine-producing country in the world (5,000 tonnes). Omar El Kayam and Layaly are some of the most popular Egyptian wines. ${ }^{148}$

\section{Other Alcoholic Fruit Juices (?)}

A great variety of fruits (approximately 14 types) was available for the consumption of the ancient Egyptian. ${ }^{149}$ There is a strong possibility that other fruit-based alcoholic beverages were consumed by the ancient Egyptian population. Interestingly, they are also referred to as "wines". These included date wine, made from the fruit of Phoenix dactylifera, the date palm tree. Palm wine, was probably made from the fermented sap of the same tree. It was obtained by incising the top of the tree at the base of the fronds. There was also fig wine, made from the Ficus Carica. There is still some controversy about whether the Egyptian term Shedeh meant pomegranate wine or pomegranate juice (genus Punica). ${ }^{150}$

146 Tamang, J. P., Watanabe, K. and Holzapfel, H.(2016). "Review: Diversity of Microorganisms in Global Fermented Foods and Beverages.", Frontiers in Microbiology, 7 (377), pp. 1-28.

${ }^{147}$ Ashenfelter, O. (2007). "Predicting the Quality and Prices of Bordeaux Wines.", The Economic Journal, 118, (529), pp. 174-184.

${ }^{148}$ Mahgoub, S., A. (2018). Fermented Food in Egypt: A Sustainable Bio-preservation to Improve the Safety of Food. PhD dissertation, Zagazig University, Egypt, pp. 35-59.

${ }_{149}$ Among these fruits are recorded: apples (Malus sylvestris), carob (Ceratonia siliqua), cherries (Prunus avium, Prunus cerasus), Christ's thorn (Zizyphus spina-Christi), lemons (Citrus medica), plums (Cordia myxa), figs (Ficus carica), grapes ((Vitis vinifera), hegelig (Balanites aegyptiaca), juniper (Oxycedrus macrocarpa), melons (Cucurbitaceae), watermelons (Citrullus vulgaris), olives (Olea europea), peaches (Prunus persica), pears (Pyrus Communis), persea (Mimusops schimperi), pomegranate (Punica granatum) and sycamore figs (Ficus sycomorus). Interestingly, Ghalioungui did not mention any juice that was produced from all these fruits. After P., Darby, W., Grivetti, L. (1977) Food: Gift of Osiris, Vol 2, Academic Press, London, Chapter 18, p. 697- 756

${ }^{150}$ Ikram, S. (2001) "Diet", in Redford, D.B. (ed): The Oxford Encyclopaedia of Ancient Egypt, Vol 1, Oxford University Press, p. 392. 


\section{Milk}

Ancient Egyptian name: irt.t.t Milk was an extremely

151 beverage for the ancient Egyptians. The reason for this is that it had many religious significances such as the association with goddesses milk with the legitimacy of ruling Egypt. The heir to the throne should be breast-fed by Isis and/or Hathor to be accepted as a lawful successor.

There was a special goddess who was given the title of the goddess of milk. Her name was Iat. ${ }^{152}$

Spells as early as the Old Kingdom Pyramid Texts confirm this idea: "Whiter art thou come, my son, O King? ...... He is come to these his two mothers, the two vultures, they of the long hair and the pendulous breasts..... They draw their breasts to his mouth, and never more do they wean him". ${ }^{153}$ On nearly every ancient Egyptian monument, young princes are depicted being nursed by goddesses; Isis offers her breast to Horus as noted in innumerable statuettes. This is considered as a clear sign of them being direct descendants of the gods. It had been hypothesised that these scenes/statues were inspiration for the early christians in the depictions of Virgin Mary and Baby Jesus. ${ }^{154}$

On many occasions, kings and royalties were shown making ritual offerings of milk or wine to the gods, especially in a specific form of jars, namely the $n w$-jars.

For the public, milk was freely given to children. In a tomb of the Eighteenth Dynasty at El-Kab, it is recorded that 60 children consumed the milk of 3 cows, 52 goats and 9 she-asses. ${ }^{155}$ Also for adults, it seems that milk was consumed on regular basis. We read in the "Tale of the Two Brothers: Inpw and Bata", which was written during the New Kingdom, that the younger brother came back every evening with the products of the field of which milk was one, although there were no children in the household ${ }^{156}$. Earlier, during the Middle Kingdom, as recounted in the "Tale of Sinuhe", at some point after his flight from Egypt, Sinuhe was "parched" thirsty and was happy to

\footnotetext{
${ }^{151} \mathrm{~Wb}$ I, 117.
}

Hieroglyphs: Rosmorduc, Serge. (2014). JSesh Documentation. [online] Available at: http://jseshdoc.qenherkhopeshef.org [Accessed 26 Dec. 2018].

${ }_{152}$ Armour, R. A. (2001) Gods and Myths of Ancient Egypt, second edition, The American University in Cairo Press, Cairo, p. 165-166.

${ }^{153}$ Pyramid Text No. 508; After Erman, (1966), n.9

${ }^{154}$ Ghalioungui,P., Darby, W. and Grivetti, L. (1977) Food: Gift of Osiris, Vol 2, Academic Press, London, p. 760

${ }^{155}$ Ruffer, M. A. (1919) Food in Egypt. Memoire presente a l'Institut Egyptien I, Imprimerie de l'Institut Francais d'Archeologie Oriental, Le Caire, p. 25.

${ }^{156}$ Papyrus D’Orbiney (British Museum 10183). After Lichtheim, M. (1976) Ancient Egyptian Literature, Vol II: The New Kingdom, University of California Press, p. 204. 
be offered boiled milk by a Beduin chief. ${ }^{157}$ Later when he lived in Retenu (Syria, nowadays), he boasted that there was milk in everything cooked. ${ }^{158}$ Milk was also mixed with medicines ${ }^{159}$.

Nowadays, fermented milk products are classified into two major groups on the basis of microorganisms: yogurt, buttermilk, natural fermented milk, cultured milk, cultured cream, cultured buttermilk; Natural fermentation is one of the oldest methods of milk processing using raw and boiled milk to ferment spontaneously, or of using the back-slopping method where a part of the previous batch of a fermented product is used to inoculate the new batch. ${ }^{160}$ Cheese and cheese products derived from the fermentation of milk are of major nutritional and commercial importance throughout the world. ${ }^{161}$

\section{Everyday Modern Egyptian Beverages}

Egyptians nowadays consume a wide variety of drinks and beverages in considerable amounts during the hot summer months as an important component of the food system. Many of the traditional drinks are based on natural products (e.g. karkadeh and fenugreek) as well as being known to have a beneficial effect on health. (Table 1) However, some have been replaced by commercially produced carbonated drinks, other soft drinks and fruit nectars. This change has entailed a significant increase in the daily sugar intake apart from depriving the body of the health benefits of the natural beverages. An extremely popular traditional Egyptian habit is consuming small glasses of sweetened black tea. It is an important source of ready calories for workers during the long interval between the waking up drink and the next meal. While tea drinking can be labelled as a national habit, coffee drinking is less popular. In general, coffee is rarely consumed among

${ }^{157}$ Lichtheim, M. (1973) Ancient Egyptian Literature, Vol I: The Old and Middle Kingdoms, University of California Press, p. 224.

${ }^{158}$ Lichtheim, M. (1973) Ancient Egyptian Literature, Vol I: The Old and Middle Kingdoms, University of California Press, p. 227.

${ }^{159}$ For more information about milk usage in medicine, refer to Nunn, J. (1996) Ancient Egyptian Medicine, University of Oklahoma Press, London, p. 148

160 Ali, A. (2010). "Beneficial Role of Lactic Acid Bacteria in Food Preservation and Human Health.”, Journal of Microbiol Research, 5(12), pp. 1213-1221. Also Ayad, E., Nashat, S., El Sedek, N.,Metwaly, H. and El Soda, M. (2004). "Selection of Wild Lactic Acid Bacteria Isolated from Traditional Egyptian Dairy Products According to Production and Technological Criteria.”, Food Microbiol, 21, pp. 15-25.

${ }^{161}$ Hamdan, Z.M.R. Ahkamanidan, H. M. and Hossein, A.A. (2014). "Milk Proteins Consideration in some Interactions.", Journal of Scientific Research and Development 1 (2), pp. 38-43. Also Gemechu, T. (2015). "Review on Lactic Acid Bacteria Function in Milk Fermentation and Preservation.", African Journal of Food Science, 9(4) pp. 170-175. 
the fellaheen and manual labourers; it is more common in urban populations as a reviving beverage especially shortly after waking up. ${ }^{162}$

\section{Conclusions}

It could be deduced that fine wines have remained throughout history the favourite drink of the high end of society, while beer and cheaper wines have been of more use to the common Egyptian.

It is noticeable that alcoholic drinks, especially beer and wine, were not used as medications but they were considered as an important vehicle, together with honey, milk and oil, for preparing ancient Egyptian medicines.

Hops was unknown for the ancient Egyptians, so they reverted to the use of other plants to give it the right flavour, therefore the lupin, skirret, and the root of an Assyrian plant were used.

Today, beer brewing and wine making and milk products are huge, extremely profitable agricultural industries..These industries have been developed from ancient and empirical knowledge from many different cultures around the world. Nowadays, the ancient knowledge has been combined with basic scientific knowledge and applied toward modern production methods. However, the manufacturing techniques have changed considerably, For example, the percentage of alcohol in both beer and wine have increased, also there are new varieties that have been added to wine e.g. sparkling wine. Concerning milk production, it is not limited to fresh milk nowadays but includes fermented milk, which is known for its benefits for a healthy lifestyle.

${ }^{162}$ Hassan-Wassef, H. (2004) "Food habits of the Egyptians: newly emerging trends", Mediterranean Health Journal, Vol. 10, No. 6, p. 8. 


\section{Figures}

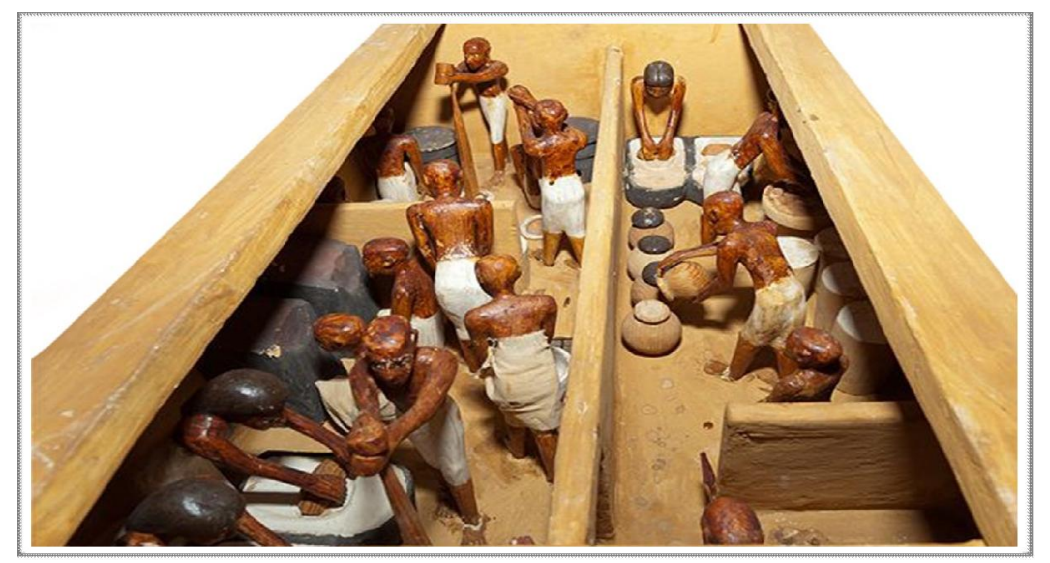

Fig (1) A wooden model of a combined bakery and brewery. From the serdab of the tomb of Meketre,12th dynasty.

Metropolitan Museum of Art, accession no: 20.3.12. Rogers Fund and Edward S. Harkness Gift, 1920.

Retrieved from the website of the Metropolitan Museum of Art https://www.metmuseum.org/toah/works-of-art/20.3.12/ Accessed on 10/11/2018.

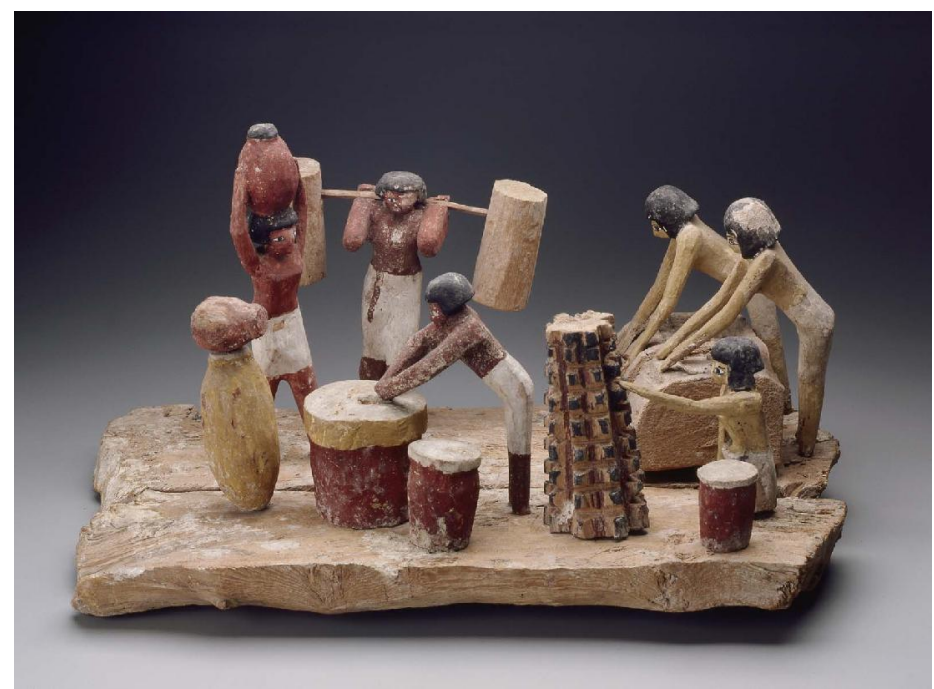

Fig (2) A model for a brewery. Tomb of Wepwawetemhat. Asyut. Middle Kingdom.

Retrieved from https://www.mfa.org/collections/object/model-of-a-brewery-45322 Accessed on 10/11/2018. 
Egyptian Beverages: A Journey through Ancient to Modern Times

Fig (3) A scene on the wall facing the entrance of the storeroom, depicting the act of baking

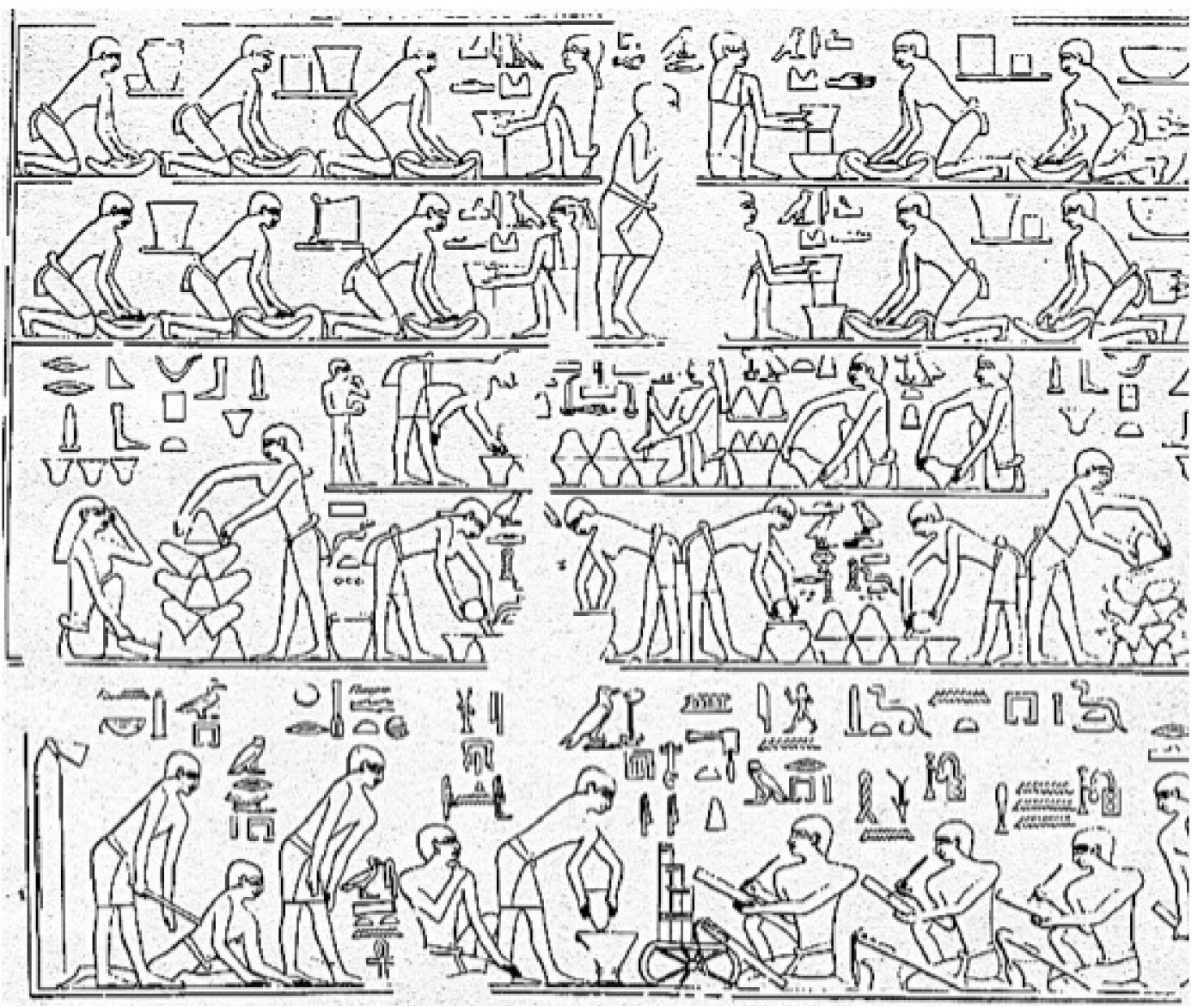

and brewing. Tomb of Ti. 5th Dynasty. Saqqara.

After Daumas, F. and Goyon, G. (1939) Le Tombeau de Ti. Memoire de l'Institut Francais d'Archeologie Orientale (MIFAO), no 65. Cairo, Institut Francais d'Archeologie Orientale, plate LXVII . 


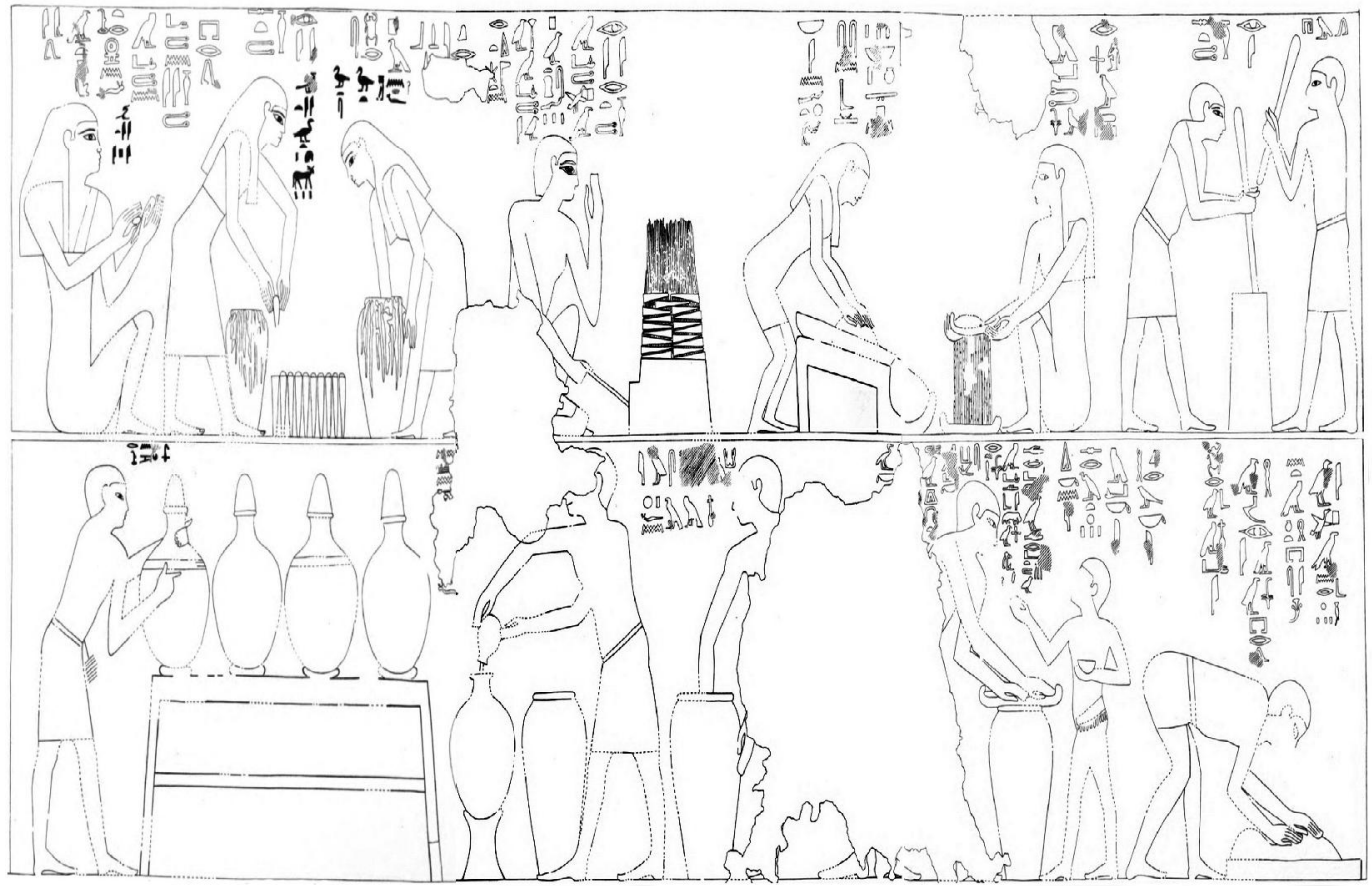

Fig (4) A scene depicting the act of baking and brewing. Middle Kingdom. Tomb of Intefiqer. Thebes (TT60) .

After Ghalioungui,P., Darby, W., Grivetti, L. (1977) Food: Gift of Osiris, Vol 2, Academic Press,London, p. 536

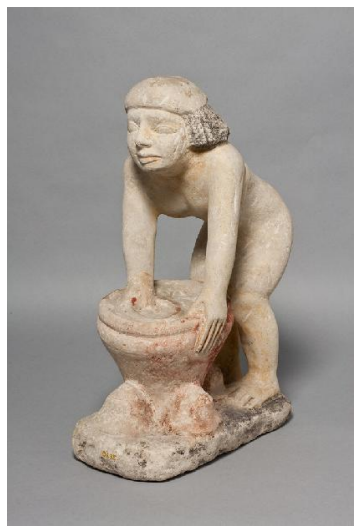

Fig (5) Statue of a Female Brewer. Probably from Giza. Old Kingdom.

It is made out of coloured limestone. Kept at the Oriental Institute of the University of Chicago, No OIC_E_10635. Retrieved from: http:/giza.fas.harvard.edu/objects/66334/intro/ Accessed on 10/11/2018 


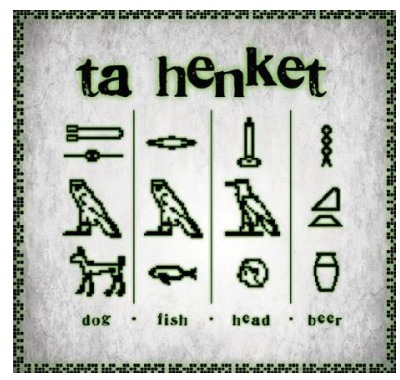

Fig (6) Label for newly re-make of ancient Egyptian Beer.

Retrieved from the website of the "Dogfish Head Craft Brewery":

https://www.dogfish.com/brewery/beer/ta-henket. Accessed on 10/11/2018

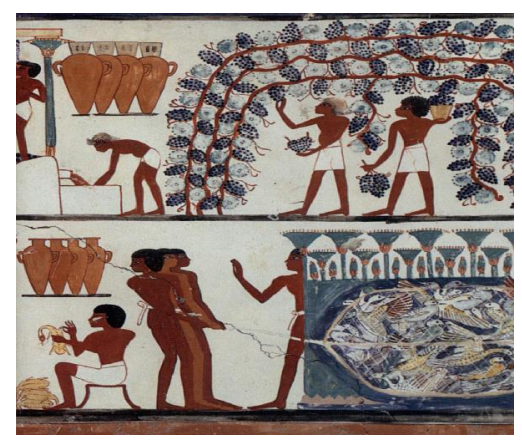

Fig (7) Bottom two registers of a wall painting from the tomb of Nakht at Thebes (New Kingdom) shows grape-harvesting and wine-making.

After McGovern, P. (July/August1998)“Wine for Eternity”, Archaeology, Vol 15, No 4, p. 29 


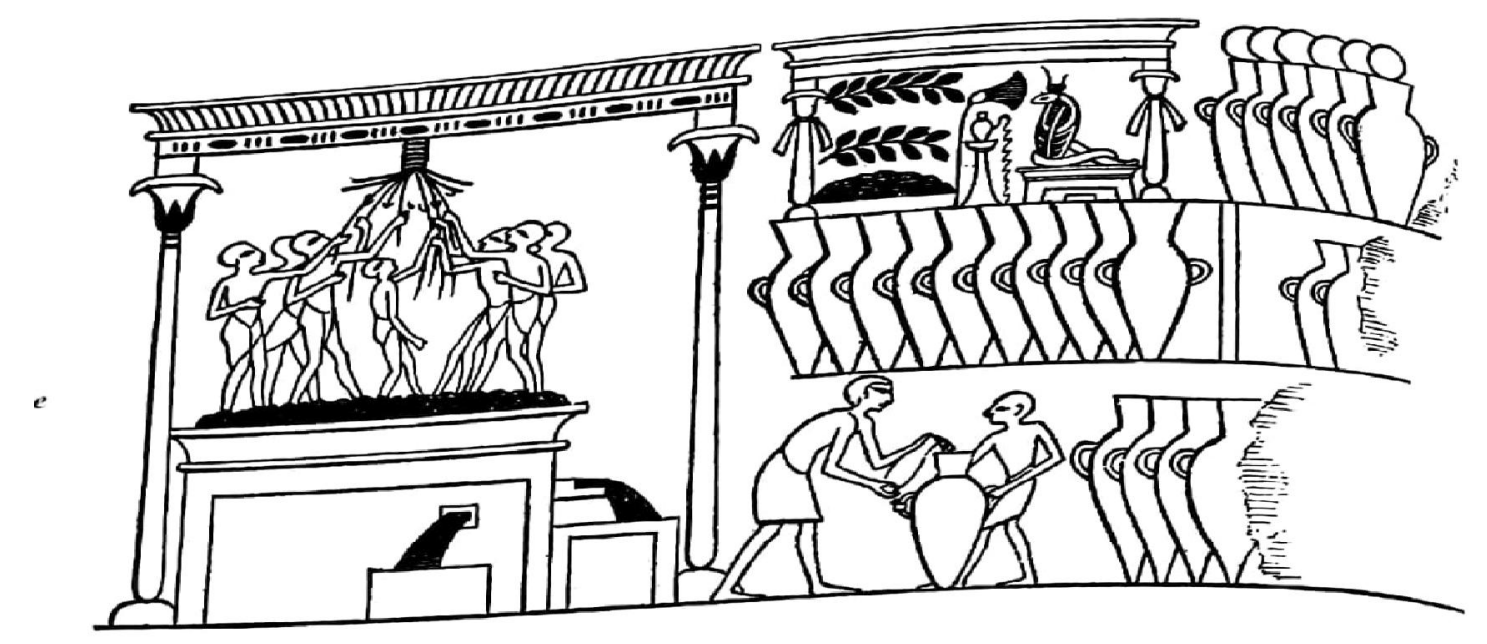

Fig (8) Scene from a Theban tomb depicting winemaking, from the New Kingdom. On the top right is a small temple to the goddess of the harvest, Renenutet, before whom is placed an offering table of grapes and wine. On the left, workers crush the grapes by foot. On the lower right, workers use jugs to fill large wine jars.

After Poo, M.-C. “Wine”, in Redford, D.B. (ed): The Oxford Encyclopaedia of Ancient Egypt, Vol 3, Oxford University Press 2001, p. 502. 


\section{Egyptian Beverages: A Journey through Ancient to Modern Times}

\section{Tables}

Table (1) A List of Traditional Beverages consumed by the Egyptians nowadays.

After Hassan-Wassef, H. " Food habits of the Egyptians: newly emerging trends", Mediterranean

Health Journal, Vol. 10, No. 6, 2004, p. 8.

\begin{tabular}{|c|c|c|c|c|c|}
\hline Cold Infusions & Hot Infusions & $\begin{array}{l}\text { Juice (Freshly } \\
\text { Pressed) }\end{array}$ & Composite Receipes & $\begin{array}{c}\text { Sherbets and } \\
\text { Syrups } \\
\text { (Now Mostly } \\
\text { Commercialised) }\end{array}$ & Other (Salted) \\
\hline $\begin{array}{c}\text { Red sorrel } \\
\text { (karkadeh) } \\
\text { Hibiscus } \\
\text { sabdariffa }\end{array}$ & Tea (black) & Sugar cane & $\begin{array}{l}\text { Moghat (traditionally } \\
\text { given to parturient } \\
\text { mothers, with ground } \\
\text { wild pomegranate root } \\
\text { as the basic ingredient) }\end{array}$ & Rose petal syrup & $\begin{array}{l}\text { Pickling water of } \\
\text { turnips }\end{array}$ \\
\hline Tamarind & Coffee & Bananas with milk & $\begin{array}{l}\text { Sahlab (a milk drink } \\
\text { made with ground } \\
\text { orchis } \\
\text { root as the main } \\
\text { ingredient) }\end{array}$ & $\begin{array}{l}\text { Violet petal } \\
\text { syrup }\end{array}$ & $\begin{array}{c}\text { Seasoned } \\
\text { Chickpeas in } \\
\text { water (Humus el } \\
\text { sham) }\end{array}$ \\
\hline Carob (kharrub) & $\begin{array}{l}\text { Fenugreek } \\
\text { (whole) }\end{array}$ & $\begin{array}{c}\text { Other fruits in } \\
\text { season e.g. } \\
\text { pomegranate, } \\
\text { mango, } \\
\text { strawberries, etc... }\end{array}$ & & $\begin{array}{l}\text { Fruit-based } \\
\text { syrups e.g } \\
\text { Strawberries, } \\
\text { berries, mango, } \\
\quad \text { etc... }\end{array}$ & \\
\hline $\begin{array}{l}\text { Licorice drink } \\
\text { (erq'soos) }\end{array}$ & $\begin{array}{l}\text { Ginger } \\
\text { (ground) }\end{array}$ & & & $\begin{array}{l}\text { Syrups made } \\
\text { from } \\
\text { concentrated } \\
\text { extracts of } \\
\text { tamarind and } \\
\text { carob }\end{array}$ & \\
\hline \multirow[t]{7}{*}{$\begin{array}{l}\text { Dom Hyphaene } \\
\text { thebaica }\end{array}$} & $\begin{array}{l}\text { Hibiscus } \\
\text { (karkadeh) }\end{array}$ & & & $\begin{array}{l}\text { Reconstituted } \\
\text { sun-dried sheets } \\
\text { of fruit pulp } \\
\text { Apricot } \\
\text { (qamareddin) }\end{array}$ & \\
\hline & $\begin{array}{l}\text { Cinnamon } \\
\text { (ground) }\end{array}$ & & & & \\
\hline & Mint leaves & & & & \\
\hline & $\begin{array}{l}\text { Cumin seeds, } \\
\text { fennel seeds }\end{array}$ & & & & \\
\hline & $\begin{array}{l}\text { Caraway } \\
\text { seeds }\end{array}$ & & & & \\
\hline & Aniseed & & & & \\
\hline & Barley & & & & \\
\hline
\end{tabular}

